\title{
Net ecosystem productivity and its environmental controls in a mature Scots pine stand in north-western Poland
}

\author{
K. Ziemblińska ${ }^{\mathrm{a}, *}$, M. Urbaniak ${ }^{\mathrm{a}}$, B.H. Chojnicki ${ }^{\mathrm{a}}$, T.A. Black ${ }^{\mathrm{c}}$, S. Niu ${ }^{\mathrm{d}}$, J. Olejnik ${ }^{\mathrm{a}, \mathrm{b}}$ \\ a Meteorology Department, Poznan University of Life Sciences, Piatkowska 94, 60-649 Poznan, Poland \\ ${ }^{\mathrm{b}}$ Department of Matter and Energy Fluxes, Global Change Research Centre, AS CR, v.v.i. Belidla 986/4a, 60300 Brno, Czech Republic \\ ${ }^{c}$ Faculty of Land and Food Systems, University of British Columbia, Vancouver, British Columbia, Canada \\ d Key Laboratory of Ecosystem Network Observation and Modelling, Institute of Geographic Sciences and Natural Resources Research, Chinese Academy of \\ Sciences, Beijing, China
}

\section{A R T I C L E I N F O}

\section{Article history:}

Received 19 February 2016

Received in revised form 24 May 2016

Accepted 31 May 2016

Available online 11 July 2016

\section{Keywords:}

Scots pine

Eddy covariance

Environmental controls

Net ecosystem productivity

\begin{abstract}
A B S T R A C T
Although there have been many studies of the net ecosystem productivity (NEP) of different types of forests around the world, the $\mathrm{CO}_{2}$ dynamics in afforested pine stands of Central Europe are poorly understood. To fill this gap, continuous eddy-covariance (EC) measurements of net ecosystem exchange (NEE) were made from January 2008 to December 2013 in a 62-year-old temperate afforested Scots pine stand near Tuczno. The site is located in north-western Poland, where forests account for almost 30\% of the land area and are dominated by Scots pine. Weather conditions during this 5-year period were mostly warm and wet. In all 5 years, air temperature $\left(T_{\mathrm{a}}\right)$ was higher than the 30-year (1983-2013) mean and by $3.3^{\circ} \mathrm{C}$ during winter 2008 , while precipitation $(P)$ was noticeably higher only in summer months. The high productivity of the forest, which sequestered $118 \mathrm{Mg}$ of $\mathrm{CO}_{2}$ per ha over the 5-year period, is likely because it was planted on fertile meadowland. Annual net ecosystem productivity ( $\mathrm{NEP}=-\mathrm{NEE})$ ranged from $494 \mathrm{~g} \mathrm{C} \mathrm{m}^{-2}$ in 2012 to $765 \mathrm{~g} \mathrm{C} \mathrm{m}^{-2}$ in 2009 , with an average of $645 \mathrm{~g} \mathrm{C} \mathrm{m}^{-2}$. The interannual variation in NEP was attributed more to the interannual variation in gross ecosystem photosynthesis (GEP) than to ecosystem respiration $(R)$. Moreover, both annual NEP and GEP significantly decreased over the 5 years. This was the result of increasingly drier springs and wetter summers as time progressed during the 5 -year period, as compared to the 30 -year averages, which resulted in a gradual reduction in the growing season NEP and consequently the annual values. Seasonal values of NEP were highly correlated with $T_{\mathrm{a}}$, photosynthetic photon flux density and vapor pressure deficit. The sensitivity of NEP to $T_{\mathrm{a}}$ was largely due to the much higher sensitivity of GEP to $T_{\mathrm{a}}$ compared to that of $R$. Although the interannual variability in NEP for separate seasons could not be explained using seasonal values of individual meteorological variables, a hygrothermal index, defined as $P / 10 T_{a}$, explained a large proportion of the interannual variability in NEP in spring and summer.
\end{abstract}

(C) 2016 Elsevier B.V. All rights reserved.

\section{Introduction}

Global forest inventory data and long-term ecosystem carbon (C) studies indicate that the global forest $\mathrm{C}$ sink is large $\left(2.4 \pm 0.4 \mathrm{Pg} \mathrm{Cy}^{-1}\right.$ ) and increasing (Pan et al., 2011). The same study revealed that in comparison to tropical and boreal zone forests, temperate forests have shown the highest rate of increase in the C sink over the past two decades: from 0.67 (1990-1999) to 0.78 (2000-2007) $\mathrm{Pg} \mathrm{Cy}^{-1}$. In addition to the forest inventory-based approach, many eddy-covariance (EC) flux studies have shown that temperate forests are C sinks worldwide (e.g., Barford et al.,

\footnotetext{
* Corresponding author.

E-mail addresses: klaziemb@up.poznan.pl,klaudiaziem@wp.pl (K. Ziemblińska).
}

2001; Pilegaard et al., 2001; Kolari et al., 2004; Zielis et al., 2014; Danielewska et al., 2015). Furthermore, according to comprehensive quantification of the $C$ balance of different forests, using EC and biometric measurements, temperate evergreen forests sequester from $133 \pm 47$ up to $389 \pm 42 \mathrm{~g} \mathrm{C} \mathrm{m}^{-2} \mathrm{y}^{-1}$ depending on climatic conditions (Luyssaert et al., 2007). In general, the large contribution of forests to the total terrestrial C sink, ca. 26\% for the period 2000-2007 (Pan et al., 2011), will have a strong influence on future climate due to its effect on $\mathrm{CO}_{2}$ exchange between the land surface and the atmosphere. Thus, there is an urgent need to investigate the effects of different climate variables in the various forest types on $\mathrm{CO}_{2}$ exchange processes. There has been considerable research into the response of evergreen forests' C exchange to climate conditions and their variation in North America, e.g. in Douglas-fir stands (Morgenstern et al., 2004; Chen et al., 2009), black spruce forests 
(Krishnan et al., 2008; Gaumont-Guay et al., 2014), white pine plantations (Arain and Restrepo-Coupe, 2004), ponderosa pine (Law et al., 2000), jack pine (Zha et al., 2009) and Europe (Ceulemans et al., 2003; Falge et al., 2002; Law et al., 2002; Baldocchi et al., 2001). Empirical relationships between $C$ fluxes and climatic factors have been developed using different approaches: simple linear and nonlinear regressions, multiple regression analysis, residual analysis, etc. (Chen et al., 2002; Chen et al., 2009). In most studies the main factors, controlling $\mathrm{CO}_{2}$ exchange are air and soil thermal and wetness characteristics and solar radiation (e.g. Chen et al., 2002; Carrara et al., 2003; Dunn et al., 2007; Barr et al., 2009; Chen et al., 2009). Therefore, in this study some of previously mentioned, commonly measured variables were chosen to investigate whether they are similarly important controlling factors of net ecosystem productivity (NEP) in Tuczno pine forest.

In Europe, where the majority of the forest area has been deforested during the past century, special afforestation policies have been implemented to compensate for this loss. This region is the only one that has had an increase in forest area (both afforestation and natural regeneration) over the past 20 years gaining ca. $0.7 \mathrm{M} \mathrm{ha}^{-1}$ since 2005 , which is slightly less than $0.9 \mathrm{M} \mathrm{hay}^{-1}$ in the 1990s. This has resulted in an increase in total forested area in Europe to $196 \mathrm{M}$ ha in the period 1990-2010 (excluding the Russian Federation), which accounts for $34 \%$ of total land area (Food and Agriculture Organization of the United Nations (FAO, 2010). The role of afforestation in the change in total forest area differs among countries, e.g. in Poland, the Czech Republic, Ireland and the UK, the contribution from natural regeneration is so small that it can be neglected, while in the Mediterranean region natural regeneration plays a major role (Zanchi et al., 2007). In this paper, it is assumed that "afforestation" means planting and/or seeding to establish forests or plantations on land not previously vegetated, classified and/or utilized as forest (Food and Agriculture Organization of the United Nations (FAO, 2010). Before World War II, Poland's forest area was depleted mainly as a result of both the expansion of agriculture and the demand for timber, but it decreased even more rapidly by 1945 when it accounted for only $20.8 \%$ of the area of Poland (Forest Research Institute, 2006). To prevent any further decrease, the National Program of Afforestation was introduced by the government, so that during the period 1945-1970 Poland's forested area increased to $27.0 \%$ of the country's area, as a result of the afforestation of $0.9 \mathrm{M}$ ha (Forest Research Institute, 2006), and recently constitutes up to $29 \%$. Since mainly Scots pine was planted in the newly established forests, this species currently accounts for almost $60 \%$ of the forest trees, and thus has become a major species in the restoration of Polish forests. (Forest Research Institute, 2013).

To fill the existing gap in the potential production assessment of a mature temperate pine forests in Central Europe, a study focusing on the controlling factors of $\mathrm{CO}_{2}$ exchange between an afforested pine stand and the atmosphere was conducted in north-west Poland. The main objectives of this study were: (1) to determine the NEP of this stand and compare it with other pine-dominated European forests; (2) to identify the main factors controlling NEP in this stand by examining the responses of gross ecosystem productivity (GEP) and ecosystem respiration $(R)$ to environmental variables at the seasonal scale.; and (3) to determine the cause of interannual variability of seasonal and annual NEP of the stand over the past five years.

\section{Material and methods}

\subsection{Site description}

The study site is located in north-western part of Poland in the Tuczno Forest District (Regional Directorate of State Forests in Piła,
Forestry Martew, $53^{\circ} 11^{\prime} \mathrm{N}, 16^{\circ} 05^{\prime} \mathrm{E}, 180 \mathrm{~m}$ a.s.l.), which is under the management of the State Forests National Forest Holding (SF NFH). The even-aged Scots pine (Pinus sylvestris L.) stand (tree age ranging from 60 to 65 years) is approximately 22.7 ha in size (approximately $500 \mathrm{~m} \times 450 \mathrm{~m}$ ) and is located on level ground (2-4\% slope) on the Drawsko Plain. The forest was planted in 1953 on a meadowland, commonly used by local farmers for cattle grazing since 1945 and formerly as farmland when it was part of Germany. The stand is surrounded by $40-80$ years old pine forest, which spreads for several kilometers in all directions. No forest treatments (except for the removal of dead trees and branches when needed) were carried out at the study site since 2008 when EC tower observations began. In 2012 a few trees within $20 \mathrm{~m}$ of the tower were removed but had no noticeable effect on measured $\mathrm{CO}_{2}$ exchange. The main tree species in the stand was Scots pine, which accounted for $99 \%$ of the trees, with an admixture of birch (Betula pendula Roth). The understory was dominated by beech (Fagus sylvatica L.) and hornbeam (Carpinus betulus L.). Forest floor flora within approximately $500 \mathrm{~m}$ of the EC tower consisted of grasses (Deschampsia flexuosa and Calamagrostis epigejos), mosses (Pleurozium schreberi), ferns (Dryopteris spinulosa) and berries (Rubus idaeus). As derived from hemispherical photographs, taken in 2008, the leaf area index (LAI) of the overstory canopy ranged from 0.83-1.5. Average height and the diameter at breast height (DBH) of the pine trees measured in 2013 were $26 \mathrm{~m}$ and $25 \mathrm{~cm}$, respectively. At that time, the stand density was estimated to be 900 trees ha ${ }^{-1}$. The average tree height during the period 2008-2013 increased by approximately $5 \mathrm{~m}$. According to the classification in the World Reference Base for Soil Resources (2006), the soil in the study area was classified as a Brunic Arenosol (Dystric). This soil, which has historically been used for agricultural purposes, has surface organic (O), A and B horizon thicknesses of about $2-5,14-25$ and $37-90 \mathrm{~cm}$, respectively. The texture of the mineral soil layers was sand to loamy sand. The average organic $C$ content, measured at 6 locations in 10 plots (ca. $20 \times 20 \mathrm{~m}$ each) surrounding the tower, ranged from 103 to $505 \mathrm{~g} \mathrm{C} \mathrm{kg}^{-1}$ soil in the $\mathrm{O}$ horizon and from 7 to $49 \mathrm{~g} \mathrm{C} \mathrm{kg}^{-1}$ soil in the A horizon.

\subsection{Climate}

The mean annual air temperature and precipitation in this region were $8.06{ }^{\circ} \mathrm{C}$ and $553 \mathrm{~mm}$ respectively as obtained for the 30-year period (1983-2013) from the nearest meteorological station, which is in Piła, about $50 \mathrm{~km}$ from Tuczno. Values from Piła were used to fill gaps in the records at the research site. Based on site data, the average length of the growing season, the aggregate period of days with mean air temperature $\geq 5^{\circ} \mathrm{C}$, was estimated to be 232 days and ranged from 216 to 251 days (over the 5 years of the study). This is consistent with the report by Koźmiński et al.(2007), which shows that average growing season length in this region is 220 days using similar methodology. The prevailing wind direction at the site was from the southwest-west to north $\left(245-360^{\circ}\right)$.

\subsection{Eddy covariance measurements}

A 38-m-tall steel scaffold flux tower $(2 \mathrm{~m} \times 2 \mathrm{~m})$ was located about $100 \mathrm{~m}$ from the eastern edge of the stand. The eddycovariance (EC) system, which was installed in January 2008, comprised a three-dimensional (3-D) non-orthogonal sonic anemometer (model CSAT3, Campbell Scientific Inc. (CSI), UK) and an open-path infrared gas analyzer (IRGA, model LI-7500. LI-COR Inc., Nebraska, USA). Both instruments were positioned above the highest platform ( $34 \mathrm{~m}$ above the ground) on a 4-m-long mast mounted vertically to the tower frame, so that the height of the EC instruments was $38 \mathrm{~m}$. This ensured that measurements were made $>1.5$ times the mean height of the trees as recommended by Burba (2013) for tall vegetation. The location of the tower ensures 
the fetch (the distance from tower to edge of the stand) was greater than $300 \mathrm{~m}$ in the direction of the prevailing winds. The longitudinal extent of the flux footprint ( $80 \%$ cumulative flux contour) for the fluxes measured at the 38-m height (calculated using the flux footprint model of Kljun et al. (2004)) was less than $300 \mathrm{~m}$ for $>70 \%$ of the acceptable measurements. Because the trees had grown by five $m$ over the five years, a second EC system was installed in January 2013 , on an adjustable mast to confirm that fluxes were constant with height and to assess the accuracy of the LI-7500 system. This system comprised a 3-D sonic anemometer (model USA1, Metek, 154 Dusseldorf, Germany) and an enclosed-path IRGA (model 7200, LI-COR Inc., Nebraska, USA). High-frequency data from both systems were analyzed independently using LI-COR EddyPro software (ver. 4.2). The second system was first mounted at the same height $(38 \mathrm{~m})$ as the main system over the period January-July 2013 and indicated no significant differences in $\mathrm{CO}_{2}$ flux measurements (Fig. 1a). After the second system was moved to the 42-m height, $\mathrm{CO}_{2}$ fluxes measured by both systems continued to show good agreement to within 90\% over the period August-December 2013 (Fig. 1b). This comparison provided confidence in the accuracy of our open-path EC measurements, and confirmed that our measurements were made in a relatively constant-flux surface layer.

\subsection{Meteorological measurements}

Some meteorological sensors were installed at the same height (approximately $38 \mathrm{~m}$ above the ground) as the open-path EC system. These comprised a meteorological station (model WXT 510/520, Vaisala Oyj, Vantaa, Finland) providing measurements of air temperature $\left(T_{a}\right)$, relative humidity $(\mathrm{RH})$ and rainfall $(P)$, as well as photosynthetic photon flux density (PPFD) using a sunshine sensor (model BF5, Delta-T Devices Ltd., Cambridge, UK). Since the WXT 510/520 was not able to measure snowfall, a heated tippingbucket rain gauge (A-ster, Cracow, Poland) was installed close to the original sensor in 2012. In September 2012, a 4-component net radiometer (model NR01, Hukseflux, Delft, the Netherlands) for measuring downwelling and upwelling solar and longwave radiation was mounted on 4-m-long boom facing south in order to avoid shading by the tower. To quantify the soil thermal regime, four heat flux plates (model HFP01, Hukseflux) were installed at the 3-cm depth about $2 \mathrm{~m}$ away from the base of the tower, and two profiles of temperature probes (model 107, CSI) were installed at $2,5,10,30$ and $50 \mathrm{~cm}$ below the soil surface (the average value from both profiles measured at the $5-\mathrm{cm}$ depth was used as soil temperature $\left(T_{\mathrm{S}}\right)$ in further analysis). Two profiles of water content reflectometers (model CS-616, CSI) for volumetric water content measurement were installed at the same location and depths as the soil temperature sensors.

All meteorological variables except $P$ were measured every $5 \mathrm{~s}$ and stored as 30-min averages/totals using CSI CR5000 and CR1000 data loggers. High-frequency raw data $(22 \mathrm{~Hz})$ were collected from the sonic anemometer and IRGA and stored on the CR5000 data logger. Data collected on both data loggers were then sent to a personal computer (PC) located in a hut at the base of the tower and stored; and the data were transferred daily to a PC in the Meteorology Department building in Poznan.

\subsection{Eddy-covariance flux calculations and quality control}

The raw data from the EC system were recorded and covariances of vertical wind speed $(w)$ and quantity of interest $\left(T_{a}, \mathrm{H}_{2} \mathrm{O}\right.$ and $\mathrm{CO}_{2}$ molar densities) were calculated to derive sensible heat, latent heat and $\mathrm{CO}_{2}\left(F_{\mathrm{C}}\right)$ fluxes, respectively. For the whole 5-year dataset we used EddyPro version 5.1 software (LI-COR Inc.) for flux calculations using a 30-min averaging period (Massman and Lee, 2002). Corrections made during computation included double rota-
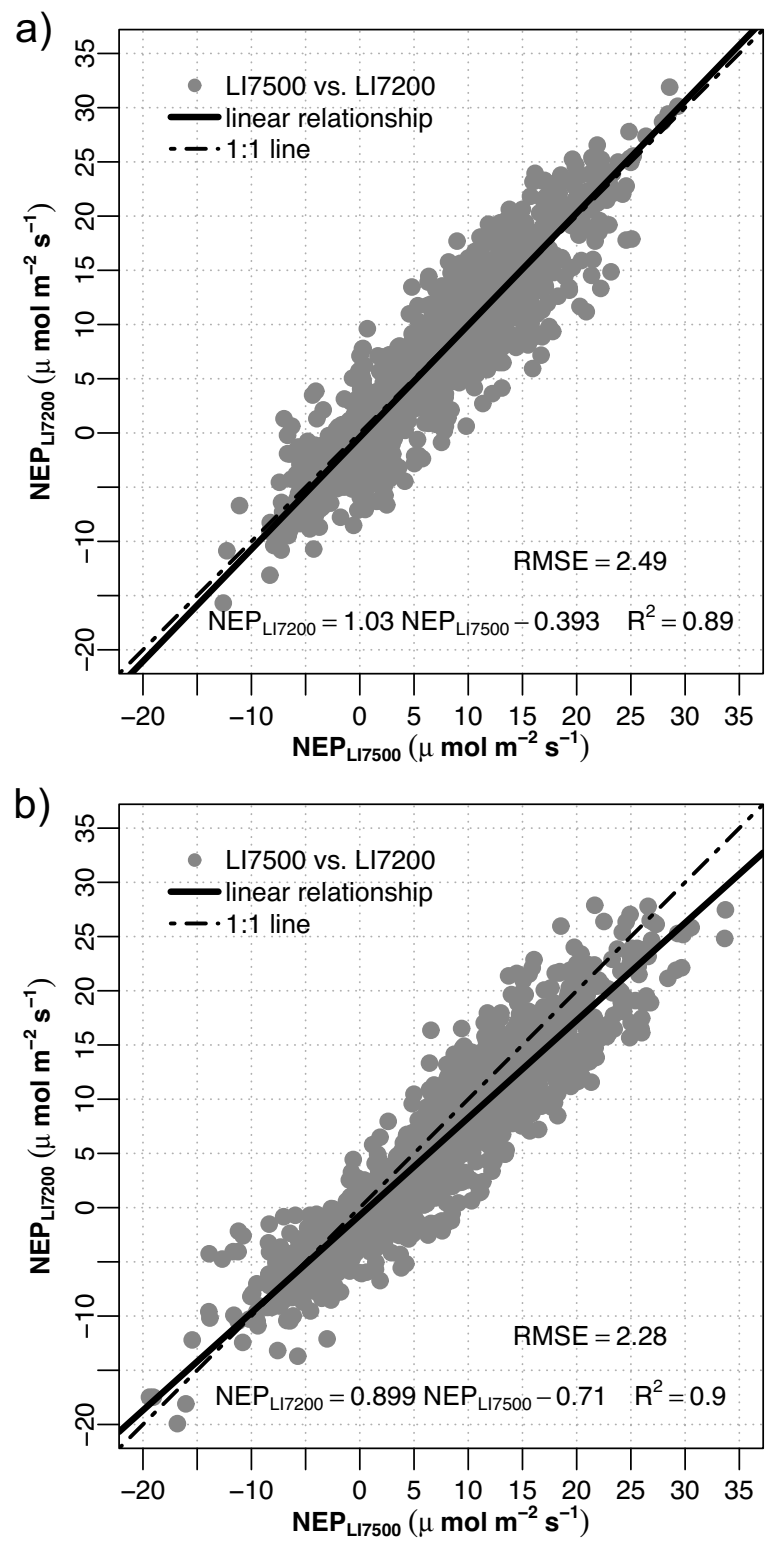

Fig. 1. (a) Comparison of half-hourly fluxes of NEP between the open-path LI-7500 (NEP7500) and the enclosed-path LI-7200 (NEP7200) analyzers mounted at the same height (38 m) in January-July 2013; (b) Comparison of half-hourly values of NEP between the open-path (NEP7500, x-axis) mounted at the "old" height of $38 \mathrm{~m}$ above the ground and the enclosed-path analyzer (NEP7200, y-axis) operating at 42-m height in August to December 2013. NEP was calculated as - NEE, where NEE is the $\mathrm{CO}_{2}$ flux plus the estimated rate of air column $\mathrm{CO}_{2}$ storage which for the two systems was the same for (a) and negligibly different for (b). The solid lines are linear regression lines and the dotted lines are 1:1 lines.

tion for tilt correction, WPL correction (Webb et al., 1980) for effects of air density fluctuations (Burba et al., 2012), covariance maximization - correcting the time lags caused by instrument spatial separation, and two frequency response corrections - analytic correction of high-pass and low-pass filtering effects (Moncrieff et al., 2004,1997 , respectively). To avoid additional errors related to the nature of EC measurements and instrument malfunctions, several steps in data $\mathrm{QA} / \mathrm{QC}$ were followed:

1. Half-hour fluxes values were filtered using the value of the IRGA's diagnostic parameter: automatic gain control (AGC), which detected measurement-path disruptions, e.g. dirt, rain drops, ice on the window, which in the case of a "clean path" should not exceed 55-65\%. Moreover, we used the diagnostic 
flag of the CSAT3 sonic anemometer to discard data obtained during periods of operation malfunction (e.g. too low or too high sonic signal amplitude, poor signal lock) which ranges from " 0 " to "1". Thus, half-hour averages of fluxes with AGC >65 and/or sonic diagnostic flag $>0$ were excluded from further analysis.

2. Fluxes obtained when the wind blew from the anemometer head or from the tower to the array (wind direction, $45-135^{\circ}$ ) were removed.

3. To assure that fluxes were measured in conditions required for the applicability of EC theory, the turbulent flux quality flag values (stationarity and developed turbulent conditions test (Foken et al., 2004; Foken and Wichura, 1996)) ranging from 0 to 2 were examined. All fluxes with quality flags greater than " 1 " were eliminated.

4. During several visual data inspections, $\mathrm{CO}_{2}$ fluxes outside the range from -50 to $+50 \mu \mathrm{mol} \mathrm{m} \mathrm{m}^{2} \mathrm{~s}^{-1}$ were removed to exclude outliers and spikes.

5. To eliminate occasional "photosynthesis" occurring at night, nighttime data were filtered, so that negative $\mathrm{CO}_{2}$ fluxes measured when PPFD $<10 \mu \mathrm{mol} \mathrm{m} \mathrm{m}^{-1}$ (nighttime indicator) were removed (ca. $3.5 \%$ of all data on average were excluded in this step).

6. All turbulent flux values that remained after the 5 previous $\mathrm{QA} / \mathrm{QC}$ steps were filtered using a friction velocity $\left(u_{*}\right)$ threshold obtained by plotting nighttime $F_{C}$ vs. $u_{*}$ for different air temperature ranges (Gu et al., 2005). The $u_{*}$ threshold used for filtering was found to be $0.2 \mathrm{~m} \mathrm{~s}^{-1}$. Fluxes measured at values of $u_{*}$ less than the threshold were discarded.

We excluded 2010 from further analysis since it had large data gaps due to instrument failure. Thus, the time period studied was from 2008 to 2013 without 2010 (i.e., 5 years). The average contribution of gaps in raw data was on average less than $30 \%$ of the half hours in all 5 years. $\mathrm{CO}_{2}$ fluxes obtained after applying all 6 steps of data filtering were marked as acceptable $F_{\mathrm{C}}$ values. The rate of change in $\mathrm{CO}_{2}$ storage in air column below the EC system $\left(\Delta S_{\mathrm{CO} 2}\right)$ (i.e., the storage flux) was computed during the first step of the calculations in the EddyPro software. Hence, net ecosystem exchange (NEE) was calculated as follows:

$\mathrm{NEE}=F_{\mathrm{C}}+\Delta S_{\mathrm{CO} 2}$

where $F_{\mathrm{C}}$ is the measured $\mathrm{CO}_{2}$ flux and $\Delta S_{\mathrm{CO} 2}$ was approximated using the product of air density, EC measurement height, and the rate of $\mathrm{CO}_{2}$ concentration change at EC measurement height (obtained using the difference between the average concentration in the 30-min periods before and after the $F_{C}$ measurement half hour (Morgenstern et al., 2004; Hollinger et al., 1994). NEP was calculated as - NEE, where positive values of NEP indicate carbon uptake by the forest. Energy balance closure (EBC), which is often used as an assessment of EC measurement quality, was calculated by linear regression of half-hour values (day and night) of latent plus sensible heat flux against the available energy flux. It was on average $75 \%$ over the 5 -year period; however, we did not adjust measured eddy fluxes to force EBC.

\subsection{NEP partitioning}

To assess GEP and $R$, we partitioned NEP values using the Fluxnet Canada Research Network (FCRN) procedure following Barr et al. (2004) and described in detail by Krishnan et al. (2009). We used the following empirical exponential function (Lloyd and Taylor, 1994) to relate nighttime and non-growing season NEE data to soil temperature (Eq. (3)).

$R=R_{\text {Tref }} \times e^{E_{0}}\left(\frac{1}{T_{r e f}-T_{0}}-\frac{1}{T_{S}-T_{0}}\right)$ where $R_{T r e f}$ is the respiration rate at a reference temperature, $T_{r e f}$ (set to $283.25 \mathrm{~K}$ ), $T_{S}$ is the measured soil temperature at the $5-\mathrm{cm}$ depth, $T_{0}$ is an estimated soil temperature between 0 and $T(\mathrm{~K})$ which is a threshold for biological activity to start (estimated for each year separately) and $E_{0}$ is the activation energy (set as a constant value of $309 \mathrm{~K}$ ). Eq. (2) was used to estimate daytime $R$ (using daytime soil temperatures) and to fill gaps in $R$ during nighttime.

GEP was estimated as NEP $+R$ (during daytime in the growing season) or zero (during nighttime and the non-growing season). The growing season indication in this procedure includes the time (each half-hour) when both air and soil temperatures were above the threshold of $0^{\circ} \mathrm{C}$. For gap filling GEP values, a rectangular hyperbola (Michaelis Menten relationship) function (Eq. (3)), modified after Falge et al., 2001; was used:

$G E P=\frac{\alpha \times P P F D}{\left(1-\left(\frac{P P F D}{2000}\right)\right)+\left(\alpha \times \frac{P P F D}{G E P_{o p t}}\right)}$

where $\alpha$ is the ecosystem quantum yield $\left(\mu \mathrm{mol} \mathrm{CO}_{2}\right.$ ( $\mu \mathrm{mol}$ quantum $)^{-1}$ ), and GEP opt is the value of GEP at an optimum PPFD value ( $2000 \mu \mathrm{mol} \mathrm{m}^{-2} \mathrm{~s}^{-1}$ was used). If necessary the input meteorological data required for gapfilling GEP and $R$ were gapfilled using measurements of surrogate variables (e.g., downwelling solar radiation for PPFD), before entering the model. Missing values of NEP were then filled with modeled GEP and $R$ values.

\subsection{Relating C fluxes to environmental variables}

Even though it is often difficult to find a clear relationship between meteorological variables and NEP itself, since it is a net effect of both $C$ uptake and release processes, NEP values were analyzed for the effects of climate variables at annual, seasonal and monthly time scales using simple linear regressions. However, the interannual variation in ecosystem functional responses of $R$ and GEP were analyzed for each specific season to ensure that the phenology of the vegetation does not change significantly. This provides insight into the sensitivity of $\mathrm{C}$ exchange processes to different meteorological conditions. We thus followed Paul-Limoges et al. (2015) in relating half-hourly C fluxes to their main climatic drivers on a seasonal basis, but instead of using non-gap-filled GEP values, we used measured daytime NEP in:

$N E P=\frac{\alpha \times P P F D}{\left(1-\left(\frac{P P F D}{2000}\right)\right)+\left(\alpha \times \frac{P P F D}{G E P_{o p t}}\right)}-R_{d}$

to obtain the parameters, $\alpha, \mathrm{GEP}_{\mathrm{opt}}$ and daytime respiration, $R_{\mathrm{d}}$, as described in Humphreys et al. (2006).

\subsection{Uncertainty calculations}

To assess the uncertainties in the annual NEP totals, calculations were made following Morgenstern et al. (2004). Final values of uncertainties for each year account for random error (set to 20\%) (Wesely and Hart, 1985) and systematic error obtained by applying both the energy balance closure correction (Kidston et al., 2010) and a value of the $u_{*}$ threshold higher than that previously used for flux filtering described in Section 2.5 ( set to $0.3 \mathrm{~m} \mathrm{~s}^{-1}$ ). To make clear the magnitude of both kinds of uncertainties, random and systematic errors are reported separately using the following convention:

$N E P_{\text {tot }} \pm E_{r}\left(E_{S}\right)$

where $\mathrm{NEP}_{\text {tot }}$ is the annual value of $\mathrm{NEP}\left(\mathrm{gC} \mathrm{m}^{-2} \mathrm{y}^{-1}\right), E_{r}$ is the random error value $\left(\mathrm{g} \mathrm{C} \mathrm{m}^{-2} \mathrm{y}^{-1}\right)$ and $E_{s}$ is the systematic error value $\left(\mathrm{gC} \mathrm{m}^{-2} \mathrm{y}^{-1}\right)$.

We followed Morgenstern et al. (2004) and Barford et al. (2001) in bracketing the systematic error since systematic biases cannot 
Table 1

Parameters for NEP vs PPFD seasonal relationships (Eq. (4)) shown in Fig. 5.

\begin{tabular}{|c|c|c|c|c|c|c|c|c|}
\hline \multirow[t]{3}{*}{ year } & \multicolumn{4}{|c|}{ Spring } & \multicolumn{4}{|c|}{ Summer } \\
\hline & $\mathrm{GEP}_{\text {opt. }}$ & $\alpha$ & $R_{\mathrm{d}}$ & $\mathrm{R}^{2}$ & $\mathrm{GEP}_{\text {opt. }}$ & $\alpha$ & $R_{\mathrm{d}}$ & $\mathrm{R}^{2}$ \\
\hline & $\mu \mathrm{mol} \mathrm{m}{ }^{-2} \mathrm{~s}^{-1}$ & $\begin{array}{l}\mu \mathrm{mol} \mathrm{CO} \\
(\mu \mathrm{mol} \text { quantum })^{-1}\end{array}$ & $\mu \mathrm{mol} \mathrm{m}{ }^{-2} \mathrm{~s}^{-1}$ & - & $\mu \mathrm{mol} \mathrm{m}^{-2} \mathrm{~s}^{-1}$ & $\begin{array}{l}\mu \mathrm{mol} \mathrm{CO} \\
(\mu \mathrm{mol} \text { quantum })^{-1}\end{array}$ & $\mu \mathrm{mol} \mathrm{m}^{-2} \mathrm{~s}^{-1}$ & - \\
\hline 2008 & 18.579 & 0.033 & 2.164 & 0.484 & 20.368 & 0.056 & 4.926 & 0.580 \\
\hline 2009 & 21.295 & 0.027 & 1.365 & 0.703 & 27.497 & 0.044 & 4.600 & 0.751 \\
\hline 2011 & 17.300 & 0.020 & 1.352 & 0.670 & 22.461 & 0.040 & 4.024 & 0.639 \\
\hline 2012 & 10.910 & 0.028 & 1.738 & 0.386 & 19.231 & 0.036 & 3.778 & 0.594 \\
\hline 2013 & 11.658 & 0.009 & 0.235 & 0.356 & 20.407 & 0.041 & 3.776 & 0.591 \\
\hline \multicolumn{5}{|c|}{ Autumn } & \multicolumn{4}{|c|}{ Winter } \\
\hline 2008 & 22.654 & 0.035 & 0.118 & 0.608 & - & - & - & - \\
\hline 2009 & 23.540 & 0.035 & 0.655 & 0.758 & 4.912 & 0.061 & 0.185 & 0.115 \\
\hline 2011 & 23.750 & 0.027 & 1.427 & 0.774 & 4.183 & 0.022 & -0.708 & 0.190 \\
\hline 2012 & 20.603 & 0.032 & 1.264 & 0.742 & -1.348 & 0.259 & -3.038 & 0.009 \\
\hline 2013 & 17.394 & 0.049 & 2.149 & 0.655 & 4.315 & 0.021 & 0.097 & 0.126 \\
\hline
\end{tabular}

be described by confidence intervals - the uncertainty in the results is not due to random noise in the measurements but to the uncertainty regarding the correct method of analysis (Morgenstern et al., 2004). Considering the investigated period, the average value of annual NEP was thus $645 \pm 10.3(130) \mathrm{g} \mathrm{C} \mathrm{m}^{-2} \mathrm{y}^{-1}$ with a range from $765 \pm 13.6$ (145) to $494 \pm 10$ (114) $\mathrm{g} \mathrm{C} \mathrm{m}^{-2} \mathrm{y}^{-1}$ (see Table 2). No sign of the systematic error denotes a positive value, which in this case means that measured fluxes were underestimated mainly due to not accounting for lack of energy balance closure (Morgenstern et al., 2004). The individual influence of a higher $\mathrm{u} *$ threshold was negative (meaning overestimation of annual NEP totals) but an order of magnitude smaller than the positive values of the lack of energy balance part so that the final values of $\mathrm{E}_{\mathrm{s}}$ were positive.

\subsection{Meteorological data averaging and regression analysis}

Although the monthly time scale is considered to be the most relevant for regression analysis between $C$ fluxes and environmental factors (Chen et al., 2009; Baldocchi et al., 2000), separate linear regressions between NEP and its climatic drivers (downwelling solar radiation (PPFD), $T_{\mathrm{a}}, P$ and water vapor pressure deficit (VPD) were performed at all three temporal scales (i.e., monthly, seasonal and annual). Half-hourly values of the meteorological variables were integrated to monthly, seasonal and annual averages or totals using Matlab software (version 7.7.0.471 (R2008b)- The MathWorks Inc.). Daytime integrations (total or average value) were calculated for the selected period when PPFD values were greater than or equal to $10 \mu \mathrm{mol} \mathrm{m} \mathrm{m}^{2} \mathrm{~s}^{-1}$. Each season was defined as a three-month period as follows: winter: December of the previous year, January and February; spring: March-May; summer: June-August and autumn: September-November. Values of winter PPFD and VPD in 2008 are missing due to lack of data in December 2007. The regression models presented in this paper were created using the above version of Matlab.

\section{Results}

\subsection{Weather conditions}

\subsubsection{Annual weather patterns}

The general annual weather pattern of a temperate climate in Central Europe is characterized by four distinctive seasons. The summer period in Poland (June-August) is the season of the highest $T_{\mathrm{a}}$ and $P$ with their maxima occurring typically in July. In order to show the representativeness of weather conditions in the analyzed years relative to the multi-year background of possible variation, a "weather conditions matrix" was generated (Fig. 2). It was divided

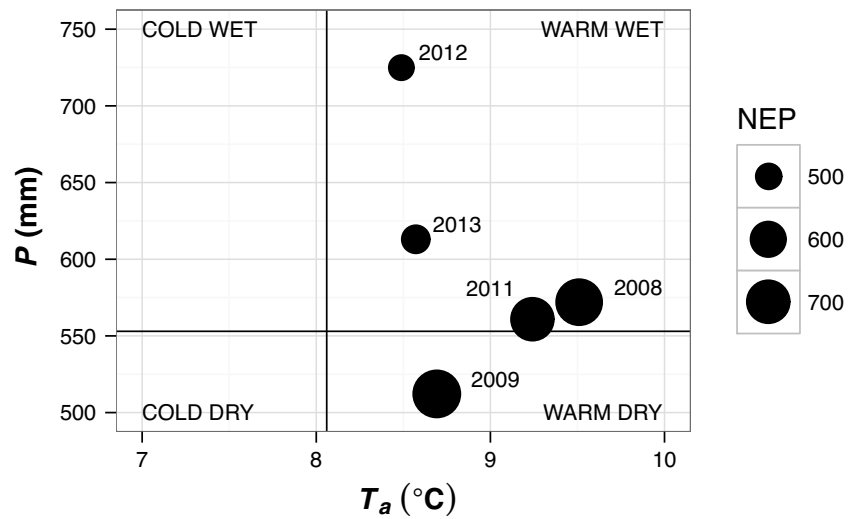

Fig. 2. Annual mean air temperature $\left(T_{a}\right)$ versus annual precipitation $(P)$, a weather conditions matrix, for 2008-2013 for the Tuczno forest. The horizontal and vertical lines are the 1983-2013 averages of $T_{\mathrm{a}}$ and $P$, respectively, for the nearby Pila meteorological station. NEP in the legend represents annual totals in $\mathrm{g} \mathrm{C} \mathrm{m}^{-2}$.

into four quadrants by two lines, representing multi-year values of mean $P$ (horizontal line) and mean $T_{\mathrm{a}}$ (vertical line), as derived from the 30-year data set (1983-2013) of daily values recorded at the Piła meteorological station. With respect to the annual mean $T_{\mathrm{a}}\left(T_{a 30}=8.06^{\circ} \mathrm{C}\right)$ and $P\left(P_{30}=553 \mathrm{~mm}\right)$ each quadrant represents thermal $\left(T_{a}\right)$ and wetness $(P)$ characteristics. The size of the symbols (filled circles) in Fig. 2 represents the magnitude of the annual total NEP in each of the five years.

As shown in Fig. 2, all 5 years of the study were warmer than the 1983-2013 average. The mean annual value of $T_{a}$ ranged from $8.49{ }^{\circ} \mathrm{C}$ in 2012 to $9.51^{\circ} \mathrm{C}$ in 2008 with the 5-year mean value being $8.90 \pm 0.45$ (standard deviation) ${ }^{\circ} \mathrm{C}$. Furthermore, except for 2009 , the values of $P$ were also higher than the 30 -year mean value, while in 2012 it exceeded the 5-year mean $(596 \pm 80 \mathrm{~mm})$ substantially. Thus 2008-2013 was represented by warmer and mostly wetter years than the 30-year average. As indicated by the size of the symbols, the two substantially wetter years had the lowest NEP (2012, 2013) while the only drier year was the most productive of all.

\subsubsection{Seasonal weather conditions}

Fig. 3 shows the seasonal patterns of weather variables as bars together with the 5-year and 30-year average values. The five-year average temperatures for spring and autumn were higher than the 30 -year average values while there was little difference for winter and summer (Fig. 3b- solid line) although winter 2008 was $3.3^{\circ} \mathrm{C}$ warmer than the 30-year average. Summer $P$ increased considerably more than average in spring and autumn (Fig. 3a). Although 
a)

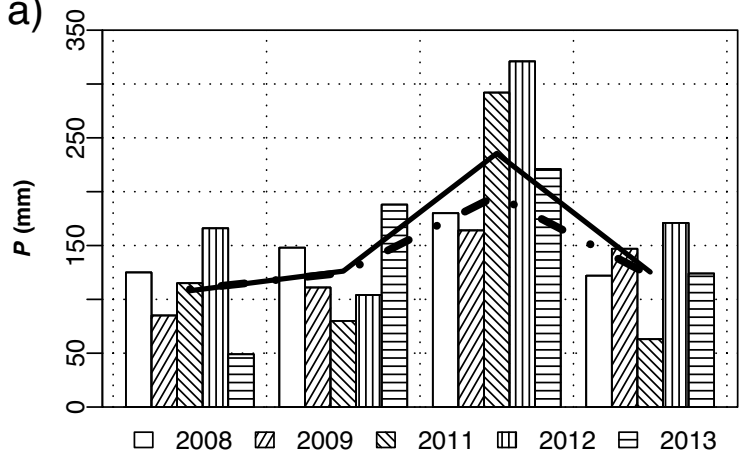

c) 8

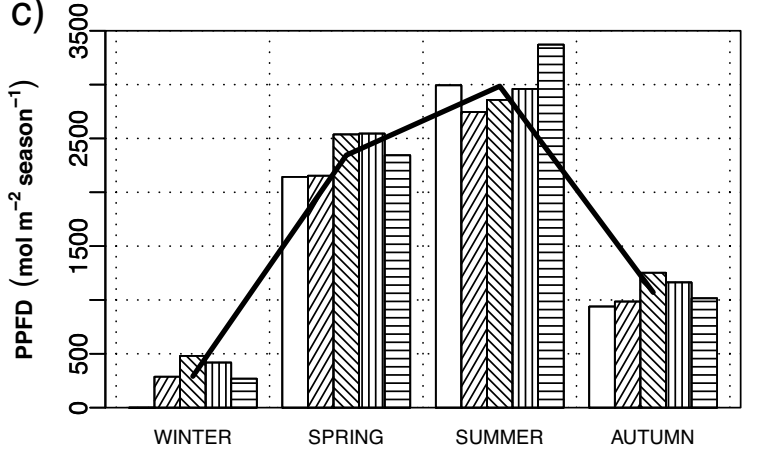

b)

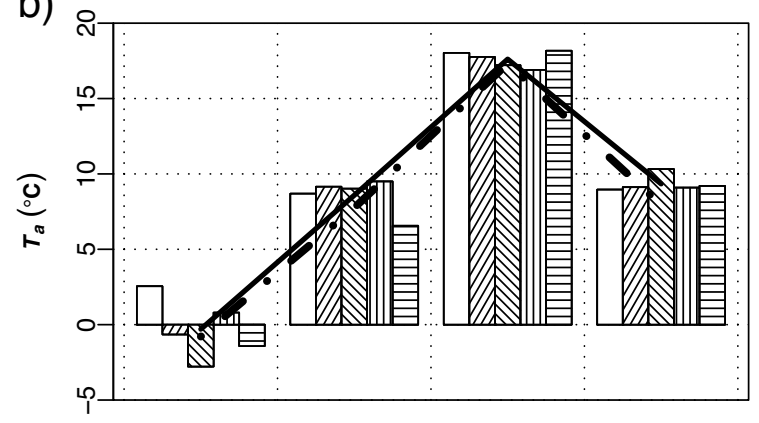

d)

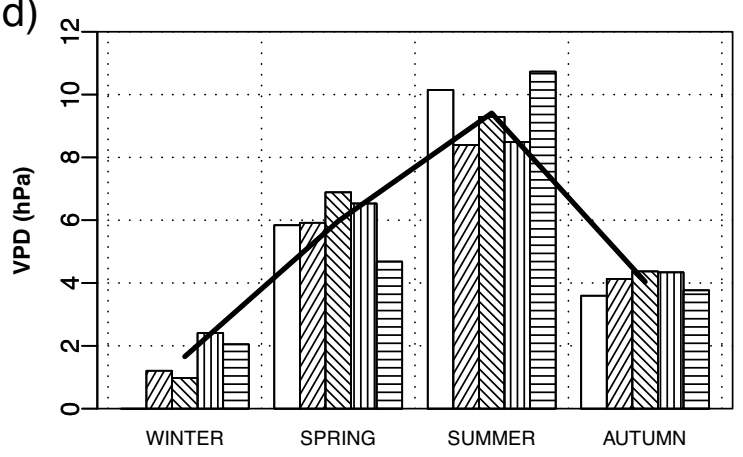

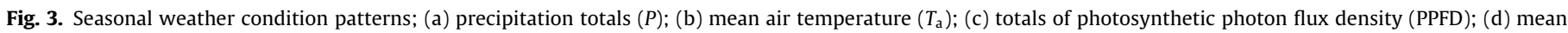

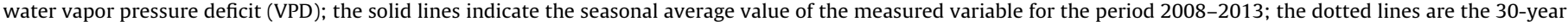
average values (data derived from the Piła meteorological station). The legend in panel (a) applies to all panels.

temperature has risen over the past 30 years, there were no clear trends in mean seasonal temperature among the five years for any season. Most of the analyzed years were characterized by drier springs and wetter summers as compared to the 30-year average values, with all autumns being warmer than in the past 30 years. PPFD for each of the seasons was generally similar for the five years except for the summer of 2013 when it was $400 \mathrm{~mol} \mathrm{~m}^{-2}$ higher than the average, which together with low $P$ likely resulted in the highest seasonal value of VPD (Fig. 3c,d, respectively).

\subsection{Functional relationships for $R$ and GEP}

\subsubsection{Nighttime half-hourly NEE (i.e. $R_{\text {night }}$ ) vs $T_{S}$}

Fig. 4 shows that the relationship between measured halfhourly NEE at nighttime followed closely the Lloyd and Taylor Eq. (2). There was a strong exponential increase in $R$ with $T_{\mathrm{s}}$ over the entire temperature range. The figure also shows that the relationship was remarkably similar for all of the five years with the exception of a tendency to decline at $T_{S}>20^{\circ} \mathrm{C}$ during 2011 and 2012 (triangles and crosses, respectively). The average respiration rate at the reference temperature $\left(T_{\text {ref }}=10^{\circ} \mathrm{C}\right)$ was ca. $2.3 \mu \mathrm{mol} \mathrm{m}^{-2} \mathrm{~s}^{-1}$ while in 2013 it was noticeably lower and equal to $1.8 \mu \mathrm{mol} \mathrm{m}^{-2} \mathrm{~s}^{-1}$. Some values at sub-zero $T_{\mathrm{s}}$ were higher than expected but could not be explained by instrument malfunction. The relationships shown in Fig. 4 were used in the gap filling of nighttime NEE and for generating daytime $R$.

\subsubsection{Relationship between daytime half-hourly NEP and PPFD}

As expected there were strong relationships between daytime half-hourly NEP and PPFD as described in Section 2.7 (Eq. (4)), with significant variation in $\mathrm{GEP}_{\mathrm{opt}}$ among investigated years. Fig. 5 shows the relationships between daytime NEP and PPFD for each of the four seasons and each of the five years.

Interannual variation in the response of seasonal NEP to changing PPFD was the highest in spring with GEP opt ranging from 21.3 to

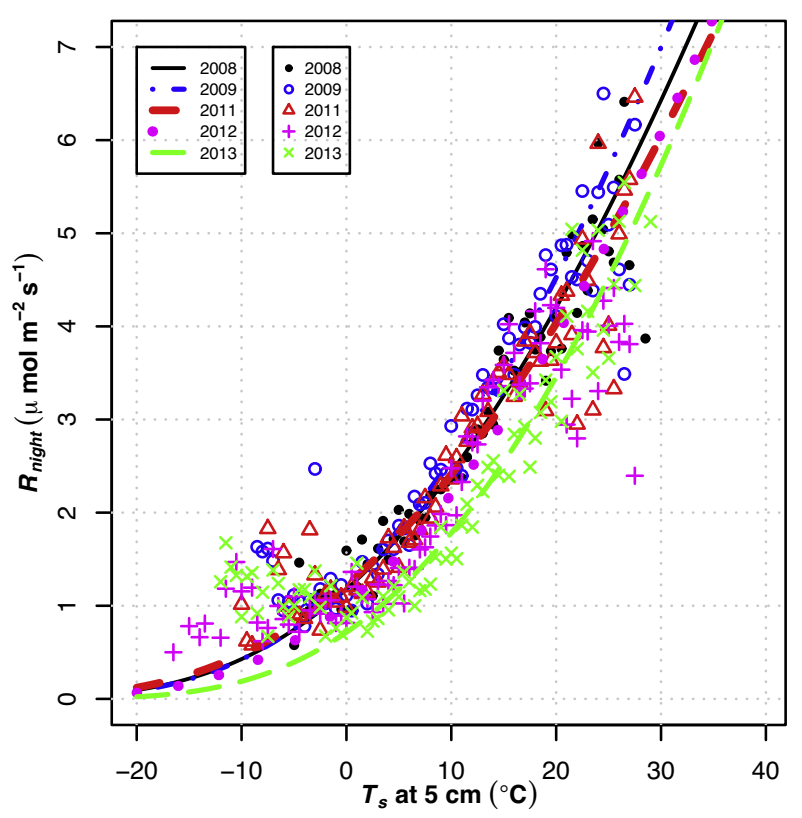

Fig. 4. The relationship between measured nighttime NEE values $\left(R_{\text {night }}\right)$ and $T_{S}$ at the 5 -cm depth. Data points are the averages of measured $R_{\text {night }}$ sorted by $T_{\mathrm{s}}\left(0.2^{\circ} \mathrm{C}\right.$ bins).

$10.9 \mu \mathrm{mol} \mathrm{m}^{-2} \mathrm{~s}^{-1}$ in 2009 and 2012 respectively (Table 1 ). Moreover, in 2009, PPFD explained more than $70 \%$ of NEP variability in spring, summer and autumn. However, during spring of 2012 and 2013, PPFD explained less than $40 \%$ of NEP variability, suggesting that other climatic factors had greater impact on carbon sequestration than PPFD. GEP opt. varied by more than 1 SD from the mean in summer 2009 only (ca. $5.5 \mu \mathrm{mol} \mathrm{m}^{-2} \mathrm{~s}^{-1}$ higher) while in spring 

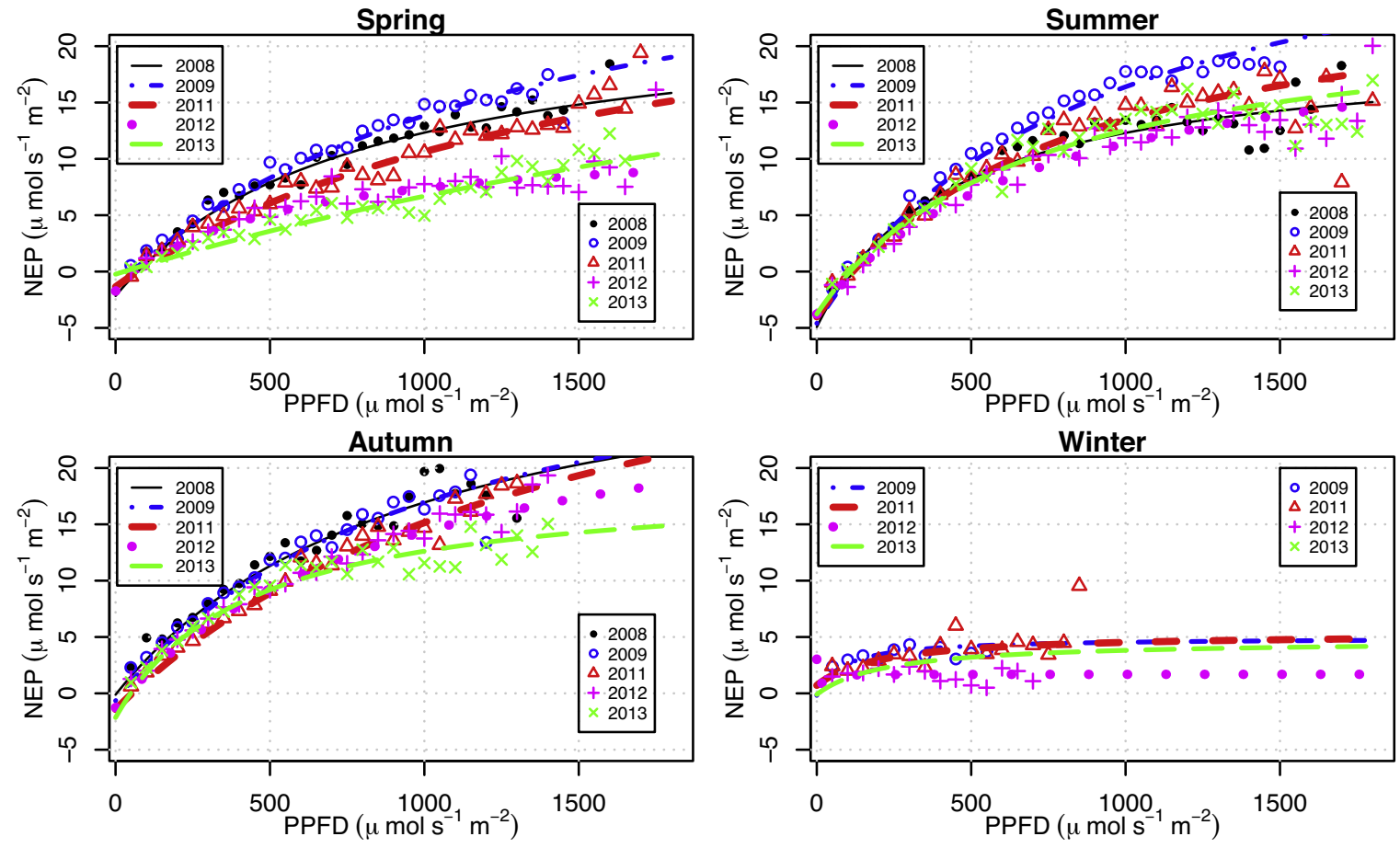

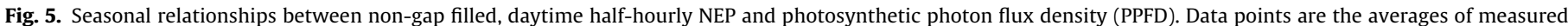
NEP sorted by PPFD ( $50 \mu \mathrm{mol} \mathrm{m}^{-2} \mathrm{~s}^{-1}$ bins). Parameters for the curves which are fitted to the half-hourly values are given in Table 1.

Table 2

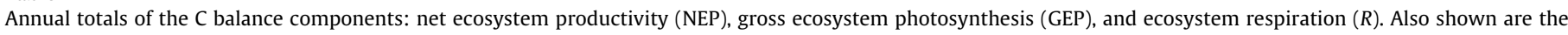

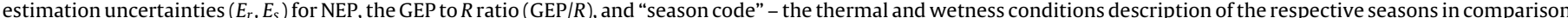

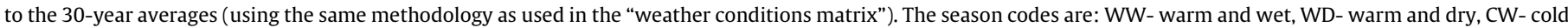
and wet or CD-cold and dry. Avg stands for the 5-year mean value, SD for standard deviation from the mean, and $c_{v}$ for coefficient of variation (SD/Avg).

\begin{tabular}{|c|c|c|c|c|c|c|c|c|c|c|}
\hline \multirow[t]{2}{*}{ Year } & \multirow{2}{*}{\multicolumn{2}{|c|}{$\begin{array}{l}\mathrm{NEP} \\
\mathrm{gC} \mathrm{m}^{-2} \mathrm{y}^{-1}\end{array}$}} & \multirow[t]{2}{*}{$E_{S}$} & \multirow[t]{2}{*}{$R$} & \multirow[t]{2}{*}{ GEP } & \multirow{2}{*}{$\frac{\mathrm{GEP} / \mathrm{R}}{-}$} & \multicolumn{4}{|c|}{ Season code } \\
\hline & & & & & & & Spring & Summer & Autumn & Winter \\
\hline 2008 & 747 & 12.1 & 145 & 1371 & 2083 & 1.52 & WW & WD & WD & WW \\
\hline 2009 & 765 & 13.6 & 145 & 1613 & 2367 & 1.47 & WD & WD & WW & WD \\
\hline 2011 & 699 & 8.8 & 171 & 1388 & 2095 & 1.51 & WD & $\mathrm{CW}$ & WD & CW \\
\hline 2012 & 494 & 8.5 & 114 & 1458 & 1947 & 1.33 & WD & CW & WW & WW \\
\hline 2013 & 520 & 8.4 & 76 & 1350 & 1863 & 1.38 & $\mathrm{CW}$ & WW & WW & $\mathrm{CD}$ \\
\hline Avg & 645 & 10.3 & 130 & 1436 & 2071 & & & & & \\
\hline SD & 128 & & & 107 & 192 & & & & & \\
\hline$c_{v}(\%)$ & & & & 7.45 & 9.27 & & & & & \\
\hline
\end{tabular}

$\mathrm{GEP}_{\text {opt. }}$ differences between years were close to or greater than 1 SD in 2009, 2011 and 2012. $R^{2}$ values, however, were higher in almost all years in summer than in spring (on average 0.63 and 0.52 , respectively). The maximum influence of other climatic factors $\left(T_{\mathrm{a}}, P\right.$, and VPD) on NEP variation during summer was observed in 2008,2013 and $2012\left(R^{2}=0.58-0.59\right)$.

\subsection{Intercomparison of C budgets - annual, seasonal and monthly time scales}

\subsubsection{Annual time scale}

Annual values of NEP, GEP, and $R$ are shown in Table 2. The 5year mean NEP, GEP and $R$ were 645, 2071 and $1436 \mathrm{~g} \mathrm{C} \mathrm{m}^{-2} \mathrm{y}^{-1}$, respectively. It was possible to reliably quantify interannual differences in NEP, as they were larger than random error, which was at most $\pm 13.6 \mathrm{~g} \mathrm{C} \mathrm{m}^{-2} \mathrm{y}^{-1}$.

The annual values of the GEP to $R$ ratio (GEP/R) were greater than 1.3 in all years, with the highest value of 1.52 in 2008 . There was a noticeable drop in this ratio from 2011 to 2012 (from 1.51 to 1.33) (Table 2). The highest annual NEP occurred in 2009 when both GEP and $R$ were the highest of all five years. After 2009, the calculated relative departures from the 5-year mean of all three components of the $C$ balance showed a decreasing trend (Fig. 6). In particular, the annual GEP steadily decreased from 2009 to 2013. The biggest reductions in NEP occurred in 2012 and 2013 with decreases of

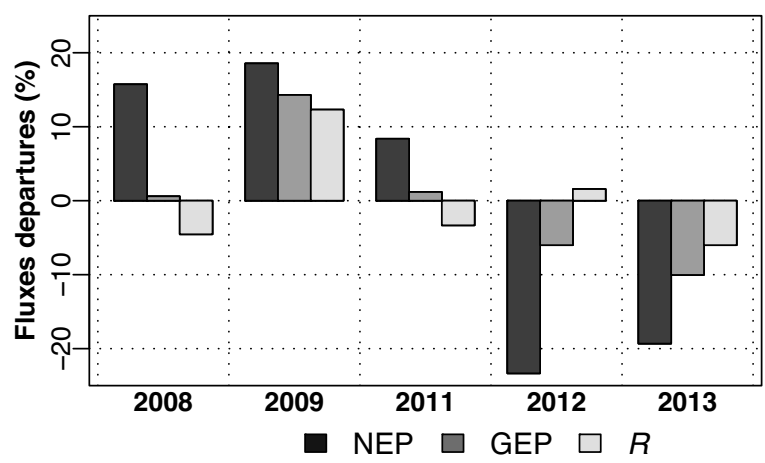

Fig. 6. Interannual variation of the $\mathrm{C}$ balance components - relative departures (\%) of the annual values of NEP, GEP and $R$ from their 5-year means (2008-2013). 
$23 \%$ and $19 \%$, respectively. Furthermore, as inferred from the coefficient of variation $\left(c_{v}\right)$, the relative interannual variation in GEP was slightly higher than that of $R$, although its absolute variation (SD) was almost twice that of $R$ (Table 2 ). Linear regression relationships between annual NEP and GEP resulted in a strong, statistically significant (at 0.1 probability significance level) correlation with $\mathrm{R}^{2}=0.705$, while the relationship for NEP vs $R$ was very weak and not statistically significant $\left(R^{2}=0.125, \mathrm{p}-\mathrm{val}=0.56\right)$.

\subsubsection{Seasonal time scale}

Winter was the only season with negative NEP values with the minimum occurring in $2013\left(-110 \mathrm{~g} \mathrm{C} \mathrm{m}^{-2}\right.$ season $\left.{ }^{-1}\right)$ and the only positive value in 2011 (Fig. 7a). Interannual variations in $R$ and GEP in spring showed a very similar pattern to that of their respective annual values (Fig. 7), with spring totals of both continuously decreasing after 2009. Such a distinct pattern was not observed for the other seasons. Despite the fact that the patterns were similar for both GEP and $R$ in all seasons, the former showed higher interannual variability (Fig. $7 d, f)$ ). There was no clear trend in the interannual variation of carbon fluxes either in summer or autumn, although summer NEP variation was much more pronounced than in autumn (Fig. 7a). The highest seasonal values of GEP and R occurred in the summer of 2009 with values of 1146 and $758 \mathrm{~g} \mathrm{C} \mathrm{m}^{-2}$, respectively (Fig. 7c,e).

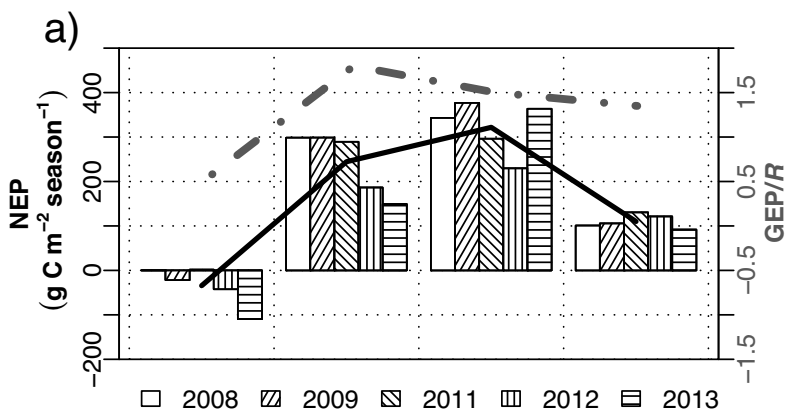

c)
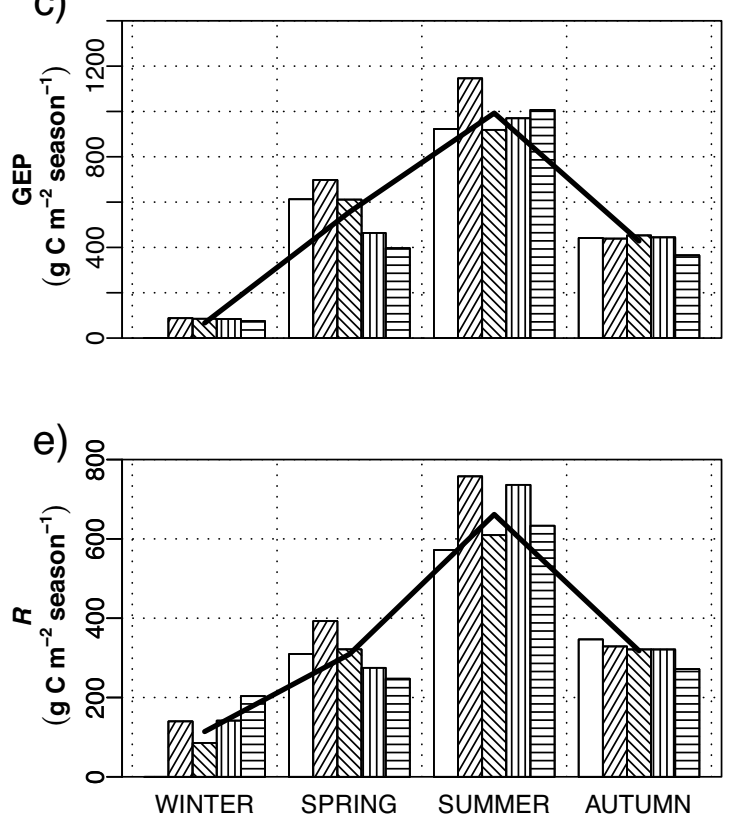

Further analysis revealed that spring and summer together accounted for more than $80 \%$ of annual NEP, while spring itself constituted up to $40 \%$. It is also noteworthy that the 5 -year average seasonal value of GEP/R jumped sharply from a winter value of 0.6 (predominance of $R$ over GEP) to reach its highest spring value of 1.8 , while the transition from summer (1.5) to autumn (1.4) was much more gradual (Fig. 7a- dotted line).

\subsubsection{Monthly time scale}

Reducing the time scale to months improved the temporal resolution of $C$ exchange dynamics as can be seen in the courses of monthly GEP/R for each of the 5 years in Fig. 8. In most years, the predominance of GEP over $R$ (i.e., GEP/R $>1.5$ ) began in February and March, while in 2013 it was delayed until early April (when average daily $T_{S}$ was less than $0^{\circ} \mathrm{C}$ until the 2nd of April). Except for 2008, the maximum value of GEP/R occurred either in April or May after which it declined significantly in early summer, remaining relatively constant during July, August and September before dropping fairly quickly in October and November.

The number of days when GEP/R $>1$ (i.e., $C$ sequestration days) was 257 on average (70\% of the year), ranging from 221 in 2013 to 288 in 2011. Even though the spring and summer values of GEP and $R$ in 2009 were the highest of the 5-year period (Fig. 7), the monthly values of GEP/R were the most similar to the mean values for the 5 -year period as shown by the dotted line in Fig. 8.
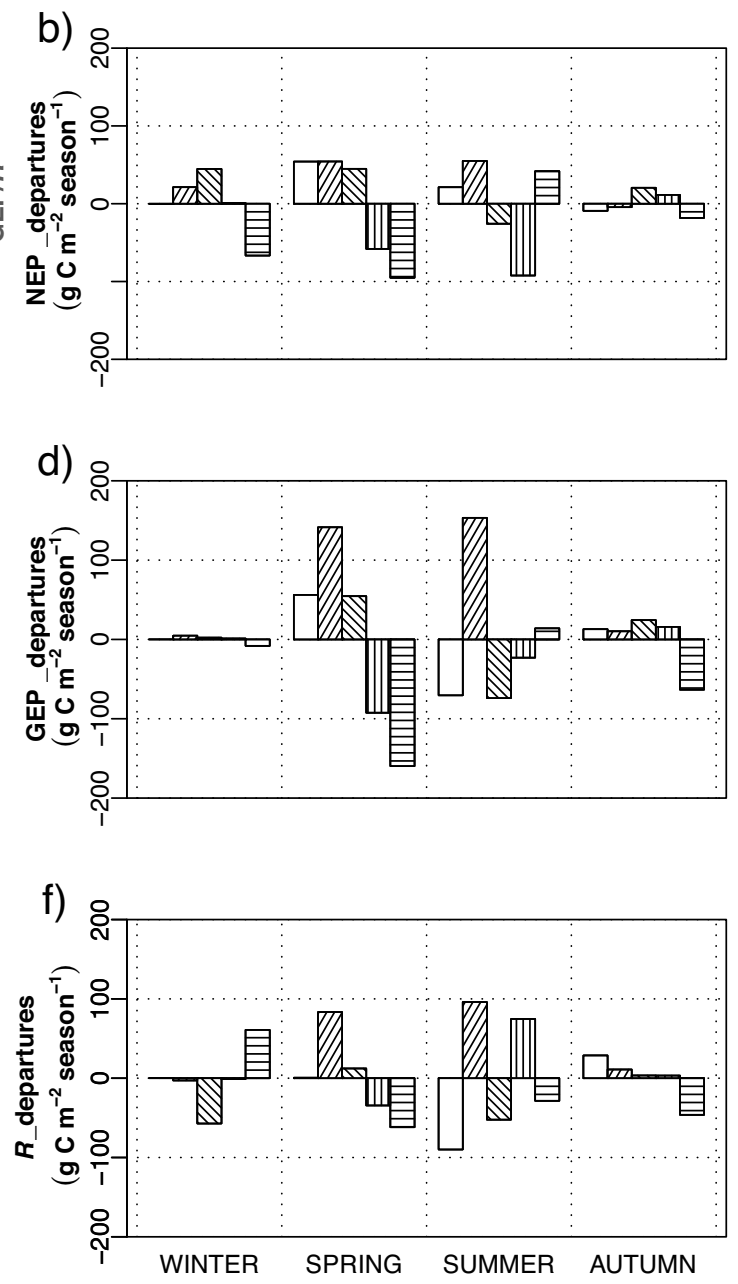

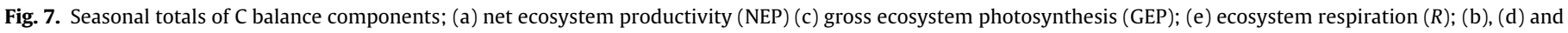

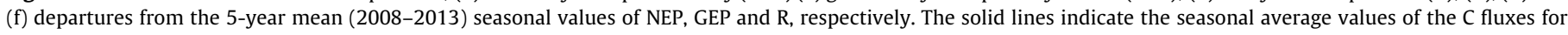
2008-2013, and the dotted line indicates the average values of GEP/R. The legend in panel a) applies to all panels. 


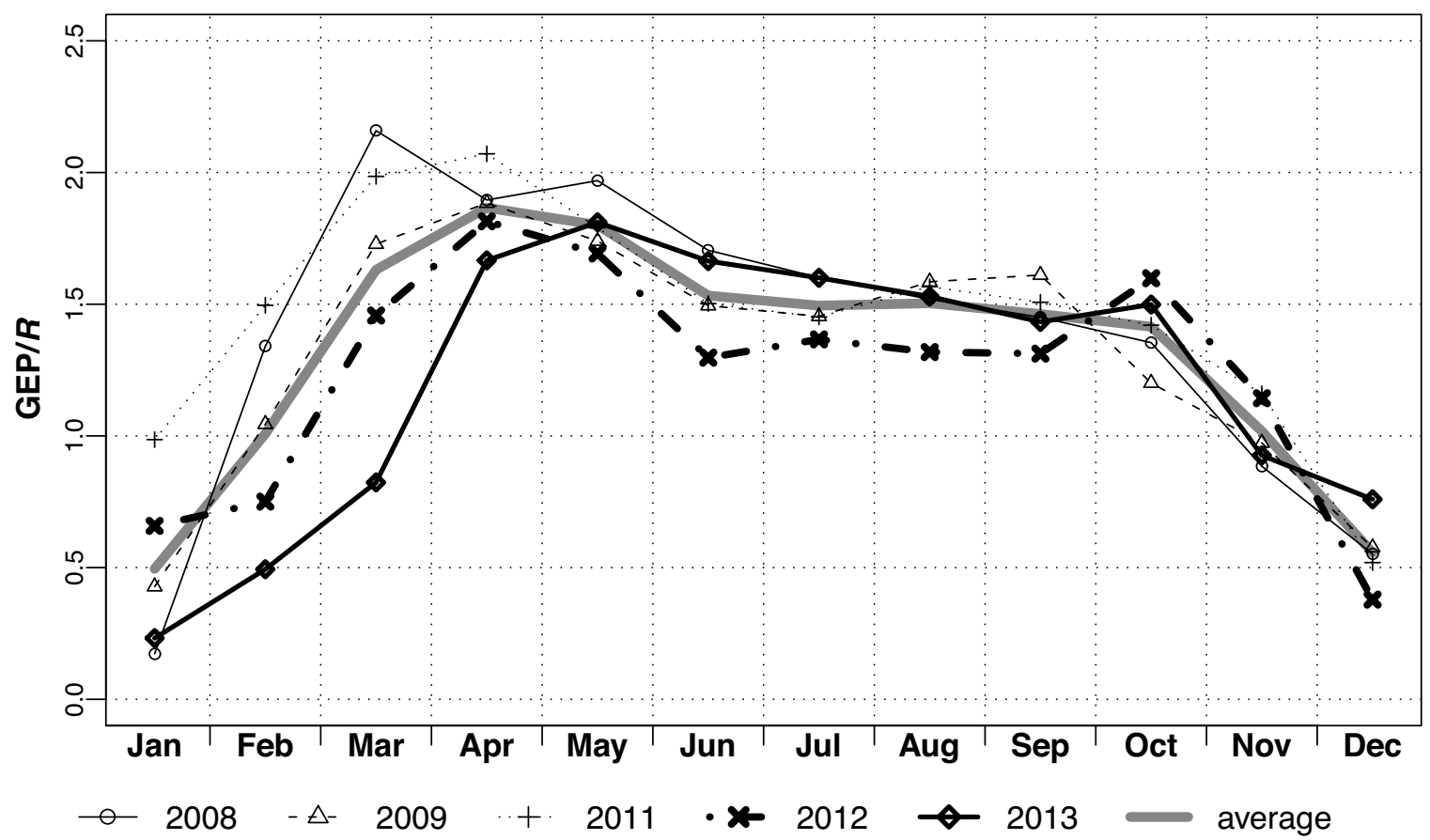

Fig. 8. Monthly values of GEP/R for the period 2008-2013.

\subsection{Climatic controls on NEP}

\subsubsection{Annual time scale analysis}

Using linear regression analysis, no statistically significant correlations were found between annual values of NEP and any of the annual variables: mean $T_{a}$, mean VPD, total PPFD, total $P$ nor their respective seasonal values (i.e., for instance spring $T_{a}$, summer VPD, etc.). Statistical significance was accepted when the $\mathrm{p}$ value was $<0.05$. The best linear correlation of annual NEP was with annual $P\left(R^{2}=0.76\right.$ with the lowest $\left.\mathrm{p}=0.054\right)$. In general, the annual analysis indicated that it is difficult to explain interannual variability of the net $\mathrm{C}$ balance using simple annual average/total values of climate variables.

\subsubsection{Seasonal time scale analysis}

Linear regression analysis for all seasons combined suggested that mean seasonal $T_{\mathrm{a}}$ explained up to $77 \%$ of the variability in NEP while PPFD and VPD explained almost 85 and $82 \%$, respectively (Fig. 9a,c and d). On the other hand, $P$ explained only $21 \%$ of NEP variability (Fig. 9b). This analysis also showed that the sensitivity of seasonal values of NEP to $T_{\mathrm{a}}$ was $\sim 19 \mathrm{~g} \mathrm{C} \mathrm{m}^{-2}$ season ${ }^{-1}{ }^{\circ} \mathrm{C}^{-1}$ which was further investigated to reveal which of carbon balance components (GEP or $R$ ) contributed more to this value. Linear regression analysis for seasonal values of GEP versus $T_{\mathrm{a}}$, and $R$ versus $T_{\mathrm{a}}$ resulted in two statistically significant relationships: $\mathrm{GEP}=48.263 T_{\mathrm{a}}+96.826$ and $R=27.749 T_{\mathrm{a}}+115.54$ with $\mathrm{R}^{2}$ in both cases about 0.9 . This shows that the sensitivity of NEP to $T_{\mathrm{a}}$ was due to the much higher sensitivity of seasonal GEP to $T_{\mathrm{a}}\left(\sim 48 \mathrm{~g} \mathrm{C} \mathrm{m}^{-2}\right.$ season $\left.{ }^{-1}{ }^{\circ} \mathrm{C}^{-1}\right)$ than that of $R$ to $T_{\mathrm{a}}\left(\sim 28 \mathrm{~g} \mathrm{C} \mathrm{m}^{-2}\right.$ season $\left.^{-1}{ }^{\circ} \mathrm{C}^{-1}\right)$.

As is evident in Fig. 9, none of tested meteorological variables individually explained the interannual variability in NEP for each of the four seasons. Therefore it was decided to combine $P$ and $T_{a}$ into a "hygrothermal index $\left(P T_{i n d}\right)$ " which was obtained by simply dividing $P$ totals by 10 times the mean $T_{\mathrm{a}}\left(P T_{\text {ind }}=P / 10 T_{\mathrm{a}}\right)$. First, $P T_{\text {ind }}$ was calculated for each month separately and then seasonal averages were determined. Values obtained were then linearly correlated with the respective NEP seasonal totals for each season separately. Surprisingly, there was a strong negative correlation in summer with $\mathrm{R}^{2}$ exceeding 0.83 , which was the only season with a statistically significant correlation (Fig. 10). For both winter (not shown) and autumn, the analysis yielded the lowest $R^{2}\left(R^{2}=0.29\right.$ and 0.07 , respectively). Unlike in other seasons when seasonal NEP showed negative correlations with $P T_{\text {ind }}$, spring was characterized by a positive response of NEP to increasing $P T_{\text {ind }}$, although statistically non-significant.

\subsubsection{Monthly time scale analysis}

The correlation between NEP and $P$ at the monthly scale was weaker than at the annual $\left(R^{2}=0.76\right)$ and seasonal $\left(R^{2}=0.20\right)$ time scales but was statistically significant $\left(R^{2}=0.10\right)$. The other weather variables also showed statistically significant correlations with $\mathrm{R}^{2}$ exceeding 0.76, with PPFD having the highest value.

\section{Discussion}

The mature Scots pine forest in this study was found to be a very productive evergreen forest ecosystem. During the period 2008-2013, the calculated mean NEP value of $645 \pm 10.3$ (130.2) $\mathrm{g} \mathrm{C} \mathrm{m}^{-2} \mathrm{y}^{-1}$ was remarkably higher than values for seven other pine-dominated forests (both temperate and boreal) in Europe (Fig. 11). The two older stands at Loobos (Netherlands) and Brasschaat (Belgium), located at similar latitude as the Tuczno forest, sequestered 505 and $142 \mathrm{~g} \mathrm{C} \mathrm{m}^{-2} \mathrm{y}^{-1}$, respectively, despite higher mean $T_{a}, P$ and LAI. Even at the warmest and wettest southern sites, San Rossore (Italy) and Le Bray (France), where forest stands dominated by maritime pine are in the same age class as our stand, and with at least two times higher LAI, the mean annual NEP values were 28 and $44 \%$ lower, respectively. These differences are due to the high GEP in the Tuczno forest, with mean annual $R$ not remarkably different between our stand and the other sites mentioned above (see Table 1 in Danielewska et al., 2015).

The Tuczno Scots pine forest, growing on the land previously used as fertile meadowland for agricultural purposes, sequestered a total of $118 \mathrm{Mg}$ of $\mathrm{CO}_{2}$ per ha over the period 2008-2013 and therefore was on average the most productive among eight pinedominated forests in Europe. For comparison, the $\mathrm{C}$ sink strength 
a)

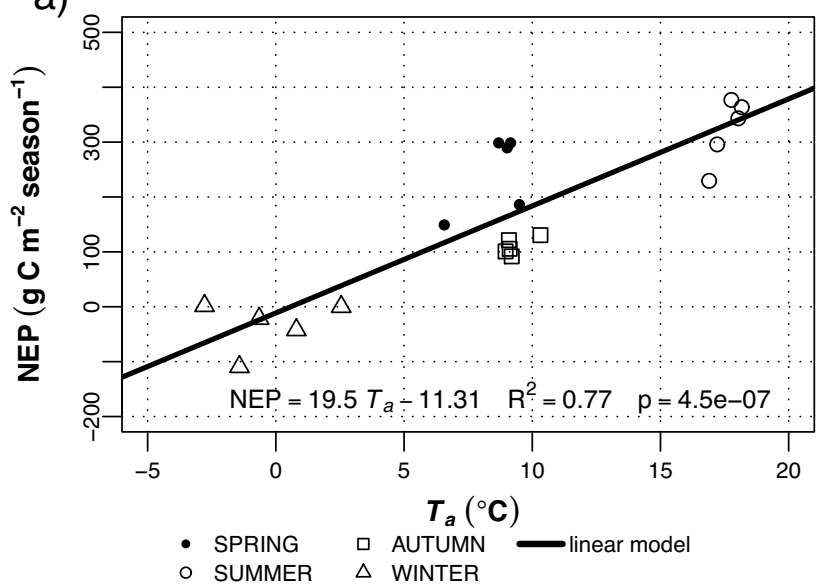

c)

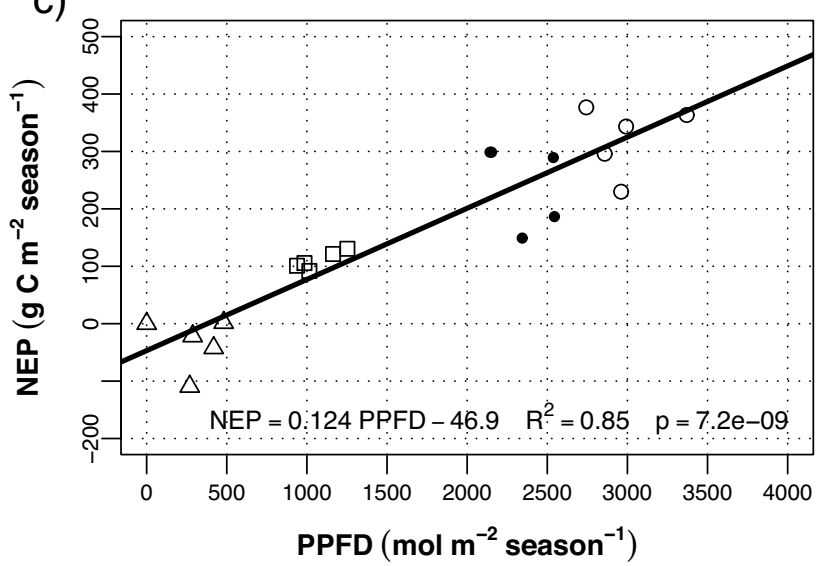

b)

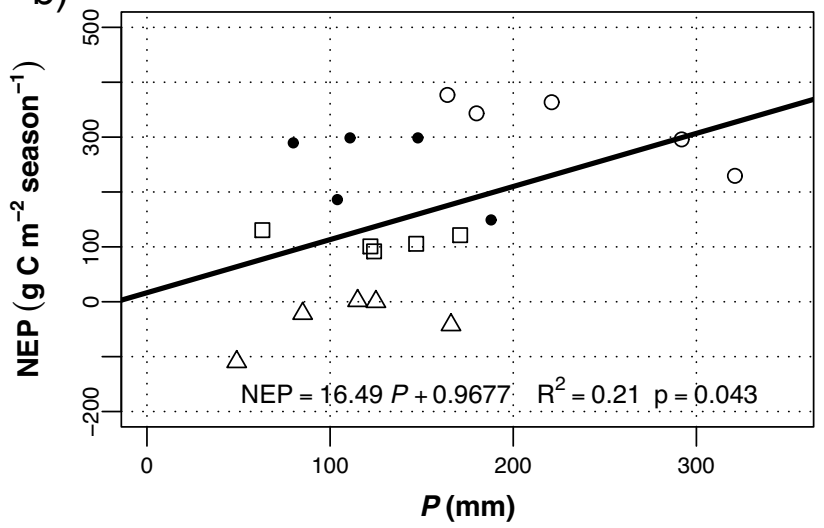

d)

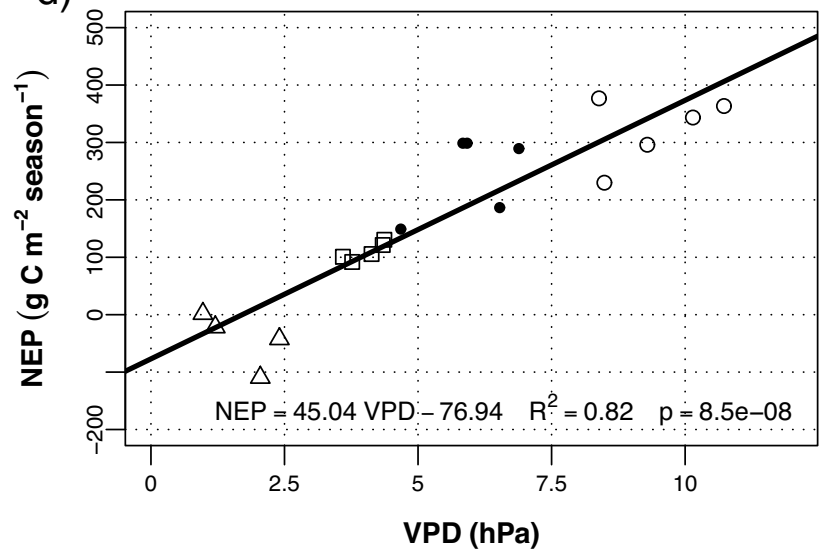

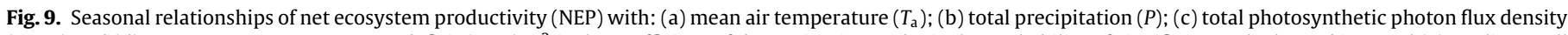

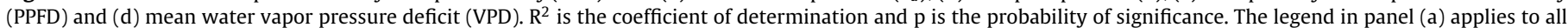
panels.

of a 65-year-old temperate white pine plantation growing on low fertility sandy soil in southern Ontario, Canada was more than three times lower, with a mean annual NEP of $196 \mathrm{~g} \mathrm{C} \mathrm{m}^{-2}$ (Arain and Restrepo-Coupe, 2004). Furthermore, the annual NEP of a Douglasfir stand in British Columbia, Canada of similar age, growing under similar thermal conditions (mean $T_{\mathrm{a}}$ ca. $8.6^{\circ} \mathrm{C}$ ) and almost three times higher annual $P$, averaged $\sim 340 \mathrm{~g} \mathrm{C} \mathrm{m}^{-2} \mathrm{y}^{-1}$ (Morgenstern et al., 2004; Krishnan et al., 2009) but increased to $\sim 550 \mathrm{~g} \mathrm{C} \mathrm{m}^{-2}$ $\mathrm{y}^{-1}$ following nitrogen fertilization (Jassal et al., 2010). This shows that better soil fertility can result in significantly higher annual NEP values in forest ecosystems.

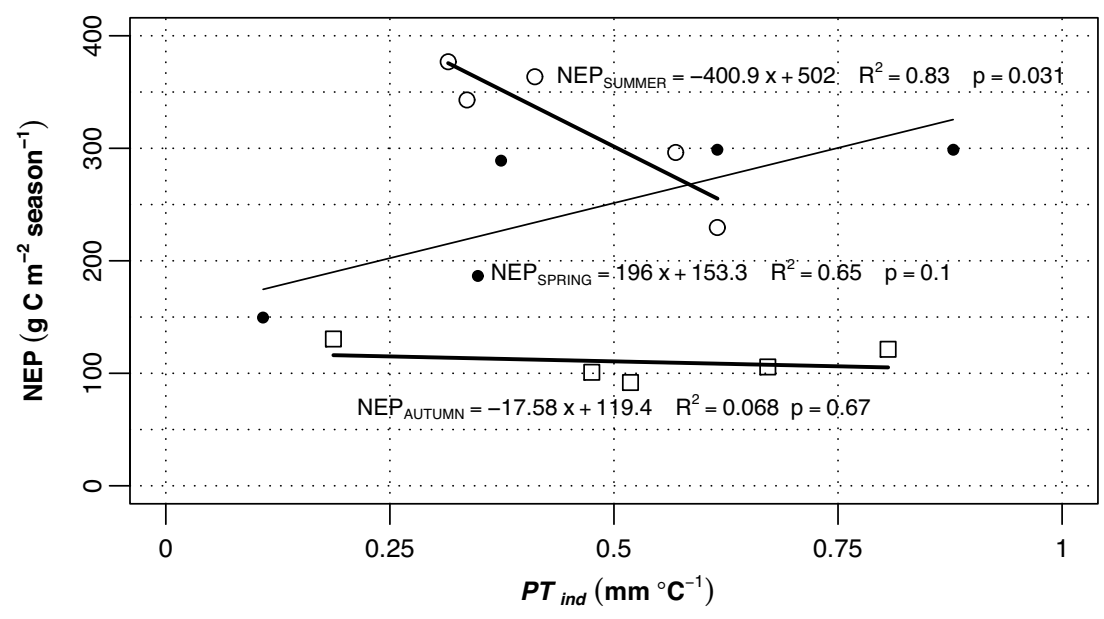

- SPRING O SUMMER a AUTUMN

Fig. 10. Seasonal relationships of net ecosystem productivity (NEP) with the hygrothermal index $\left(P T_{\text {ind }}=P / 10 T_{\mathrm{a}}\right)$. 


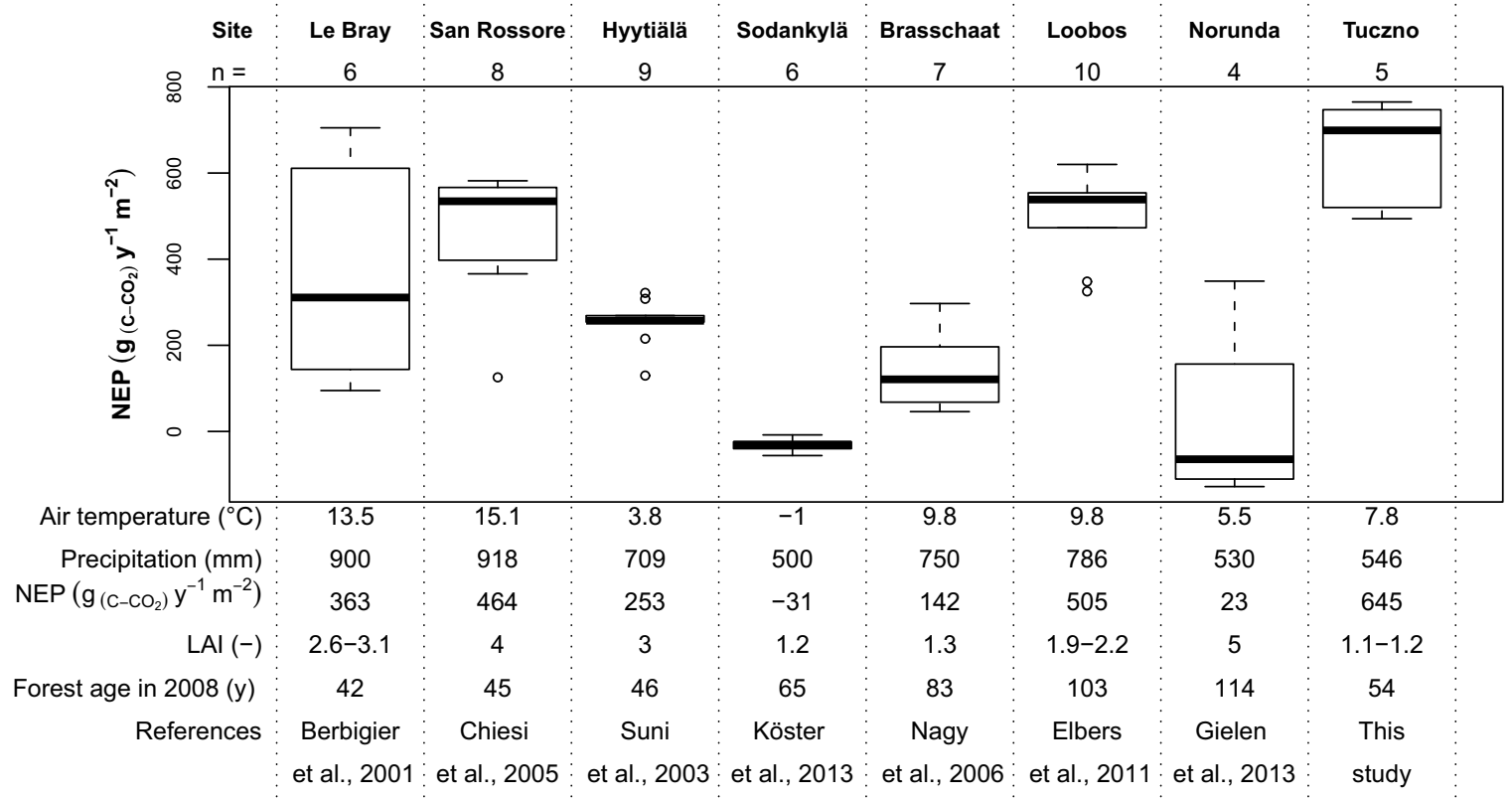

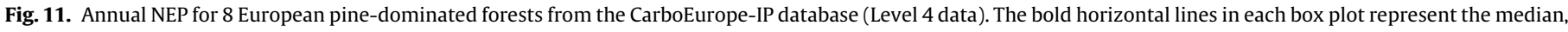

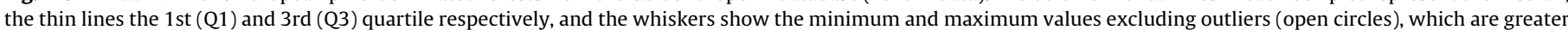

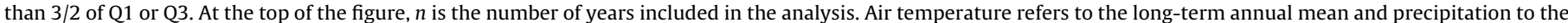
long-term annual sum. (Berbigier et al., 2001; Chiesi et al., 2005; Elbers et al., 2011; Gielen et al., 2013; Köster et al., 2013; Nagy et al., 2006; Suni et al., 2003).

The limited amount of available data did not show any significant relationship between annual NEP and major meteorological drivers. Further analysis of the seasonal and monthly values revealed that $T_{\mathrm{a}}$, PPFD and VPD explained a large proportion of NEP variability in both cases. Moreover, higher sensitivity of seasonal GEP to $T_{a}$ compared to $R$ explained the large positive sensitivity of NEP to $T_{a}$. In general, individual meteorological variables could not satisfactorily explain interannual variability in NEP of individual seasons so that a hygrothermal index $\left(P T_{\text {ind }}=P / 10 T_{a}\right)$ was introduced to combine the impact of $T_{a}$ and $P$ on net $C$ exchange. Separate linear regressions between seasonal NEP and $P T_{\text {ind }}$ revealed that in summer NEP was negatively correlated to hygrothermal index indicating that under moderate $T_{a}$ high precipitation (meaning high $P T_{\text {ind }}$ ) in summer reduces $C$ sequestration. It can be explained by enhanced $R$ due to increased soil moisture (noticeable in case of 2012) but it also suppressed GEP which can be attributed to less solar radiation due to overcast conditions during rain events. However, spring NEP increased with increasing $P T_{\text {ind }}$. It is interesting to note that spring 2011 and 2012 were similar in terms of $T_{a}$ to 2009 but with lower $P$, while spring 2013 was wet but significantly cooler than in any other year. Meteorological conditions in both seasons had thus a substantial effect on interannual NEP. Spring and summer contribution to annual NEP was on average as much as $80 \%$, similar to the above-mentioned Douglas-fir stand (Chen et al., 2009). While there was no correlation between annual NEP and mean spring $T_{a}$ for the Tuczno forest, Krishnan et al., 2009 found that interannual variability in the $C$ balance of different-aged Douglas-fir stands was caused by year-to-year variability in spring temperature and water availability in late summer. In Tuczno, spring cooling and drying (most of the analyzed years had dry spring in comparison to 30-year average) seems to diminish GEP more than it reduces $R$, resulting in a decrease in NEP (Fig. 7a-e) during the 5-year period. It will be interesting to see how other ecosystems will respond if the increased summertime $P$ trend continues in the future.

Seasonal GEP/R (Fig. 7a) showed that there was much more dynamic predominance of GEP over $R$ in the Tuczno forest from winter to spring with the ratio increasing from 0.6 to 1.8 , while the transition from summer to autumn was much more gradual. This is an additional argument that climatic conditions at the beginning of the growing season are crucial for annual NEP determination. Departures in annual $\mathrm{C}$ balance component values from the 5 -year means suggest that after 2009, NEP decreased because of decreasing GEP (10\% less in 2013 than the 5-year average), which exceeded the corresponding decline in $R$ (about 6\%- Fig. 6). Moreover, as inferred from the coefficient of variation $\left(c_{v}\right)$, the interannual variation in GEP was higher than that of $R$ (Table 2). The lowest annual NEP, which occurred in 2012, was explained by reduced GEP (as in 2013) and also the second highest $R$, possibly because of the abnormally high $P$ in the summer (almost twice as high as normal). Rain events provided moisture to the soil that enhanced $R$. This is also noticeable in the case of the monthly GEP/R values (Fig. 8), where this ratio in the summer months of 2012 (June-September) was the lowest of all years. Unlike in 2012, the decrease in annual NEP in 2013 resulted from the lower than normal temperatures in spring with the growing season starting at the beginning of April that significantly delayed the onset of photosynthetic activity (see Fig. 8). The seasonal behavior of the $C$ fluxes provides an additional indication that the interannual variation of NEP was largely a result of variations in GEP rather than in $R$. As mentioned above, among all seasons, summer and spring played a major role in determining the annual NEP value since they accounted for up to $80 \%$ of the annual value. Winter was the only period with negative NEP values with the minimum occurring in 2013, which resulted from the highest $R$ of all years (Fig. 7a,f). The most probable reason was the $P$ distribution - almost $80 \%$ of winter $P$ in 2013 occurred over 22 days with mean daily $T_{a}$ and $T_{S}$ above $0{ }^{\circ} \mathrm{C}$. To summarize, GEP variability was more important than variability in $R$ in determining the interannual variation in NEP of mature temperate pine forest in Poland and this effect was noticeable at both annual and seasonal scales. This is opposite to the conclusion of Morgenstern et al. (2004) who found that interannual differences in NEP of a 52-yearold Douglas-fir stand were mainly due to the $R$. Chronosequence studies of temperate conifer plantations in Canada (white pine) and 19 other temperate forests, showed results similar to ours, i.e., 
GEP, rather than $R$, playing a dominant role in net $C$ uptake of both plantations and natural forests (Arain and Restrepo-Coupe, 2004).

Regarding the key drivers of NEP in the Tuczno forest, a large proportion of variance in seasonal and monthly NEP was explained by $T_{\mathrm{a}}$, PPFD and VPD. However, a lower $\mathrm{R}^{2}$ for the relationship between NEP and PPFD during spring suggested a greater importance of climatic factors other than solar irradiance (Fig. 5). In 2013, spring $T_{a}$ was significantly lower than in any other year with mean daily $T_{s}$ below $0{ }^{\circ} \mathrm{C}$ almost $27 \%$ of the time which means soil freezing and thus limited access to ground water by tree roots. Even though there was no difference in thermal and moisture conditions between spring 2011 and 2012 (moderate $T_{a}$ and low $P$ in both cases) the performance of the hyperbolic function was much worse for 2012. Also, winter $P$ in 2012 was as much as 30\% higher than in 2011 and all other years (Fig. 3a). This may have resulted in slower snowmelt in spring and thus a delayed onset of understory photosynthetic activity (see also Fig. 8). In general, autumn NEP was best correlated with PPFD (the highest $\mathrm{R}^{2}$ value) showing less interannual variability in seasonal $\mathrm{GEP}_{\text {opt }}$ in autumn than summer and spring, with 2013 being exceptionally the worst case (Fig. 5). There is no clear reason for such a decline in $\mathrm{GEP}_{\text {opt. }}$ in that year except for the hypothesis that high summer VPD perhaps resulted in tree water stress, from which the trees were not able to recover in autumn. The poorest response of seasonal NEP to seasonal PPFD occurred in winter especially in 2012 when a 3-week-long snowfree freezing period occurred. When $T_{\mathrm{a}}$ and $T_{\mathrm{s}}$ fell below $0^{\circ} \mathrm{C}$, it was assumed that there was no photosynthesis so only $R$ determined NEP. Under such conditions of low temperature and lack of snow cover, $R$ was restricted substantially. Even with relatively high PPFD (in comparison to warmer rainy days), NEP was very small in 2012. The maximum influence of other factors on NEP variation during summer was observed in 2008, 2012 and 2013, which in case of 2008 and 2013 was likely the result of high VPD. The summer of 2012 was, in contrast, the wettest summer of all with some very high intensity rain events.

\section{Conclusions}

The main conclusions from the analysis of 5 years (2008-2013) of NEE measurements in a mature Scots pine stand in northwestern Poland are as follows:

1. The Tuczno Scots pine forest was the most productive ecosystem in comparison with seven others pine-dominated forests in Europe, sequestering on average $645 \mathrm{~g} \mathrm{C} \mathrm{m}^{-2} \mathrm{y}^{-1}$, likely because it was growing on formerly fertilized meadowland.

2. The interannual variation of annual NEP was largely the result of variations in annual GEP rather than in annual $R$ (the interannual variation in GEP was higher than that of $R$ at the annual time scale).

3. The seasonal values of NEP over the five years were highly correlated with $T_{\mathrm{a}}$, PPFD and VPD. The sensitivity to $T_{\mathrm{a}}\left(\sim 19 \mathrm{~g} \mathrm{C} \mathrm{m}^{-2}\right.$ season $\left.{ }^{-1}{ }^{\circ} \mathrm{C}^{-1}\right)$ was largely due to the much higher sensitivity of GEP to $T_{\mathrm{a}}\left(\sim 48 \mathrm{~g} \mathrm{C} \mathrm{m}^{-2}\right.$ season $\left.^{-1}{ }^{\circ} \mathrm{C}^{-1}\right)$ compared to that of $R$ $\left(\sim 28 \mathrm{~g} \mathrm{C} \mathrm{m}^{-2}\right.$ season $\left.{ }^{-1}{ }^{\circ} \mathrm{C}^{-1}\right)$.

4. It was not possible to satisfactorily explain the interannual variability in NEP for separate seasons using seasonal values of individual meteorological variables; however, a hygrothermal index $\left(P / 10 T_{a}\right)$ explained a large proportion of the interannual variability in NEP in spring and summer.

\section{Acknowledgements}

This research was supported by funding from States Forest National Forest Holding in Poland (project LAS, No OR-2717/27/11).
We would like to express our gratitude to technicians and PhD student from Meteorology Department from Poznań University of Life Sciences for their support during fieldwork. We kindly acknowledge CarboExtreme (EU-FP7), CarboEuropeIP (EU-FP6), GHG-Europe (EU-FP7), IMECC (EU-FP6) projects and all PIs of European pine forest station incorporated in CarboEurope-IP database, namely: Eddy Moors of Alterra Wageningen UR, Reinhart Ceulemans, Ivan Janssens, Denis Loustau, Alessandro Cescatti, Carsten Gruening, Anders Lindroth, Timo Vesala, Ivan Mammarella, Tuomas Laurila, Achim Grelle, Maria Jose Sanz and Arnaud Carrara for the permission to use the data for comparison with Tuczno pine forest. We would like to thank Rachhpal Jassal from the Faculty of Land and Food Systems at the University of British Columbia (Vancouver, British Columbia, Canada) for providing valuable comments, edits and suggestions during manuscript preparation.

\section{References}

Arain, M.A., Restrepo-Coupe, N., 2004. Net ecosystem production in a temperate pine plantation in southeastern Canada. Agric. For. Meteorol. 128 (3-4), 223-241, http://dx.doi.org/10.1016/j.agrformet.2004.10.003.

Baldocchi, D., Falge, E., Wilson, K., 2000. A spectral analysis of biosphere-atmosphere trace gas flux densities and meteorological variables across hour to multi-year time scales. Agric. For. Meteorol 2915 (2000), 1-27.

Baldocchi, D.D., Falge, E., Gu, L., Olson, R., Hollinger, D., Running, S., Anthoni, P., Bernhofer Ch Davis, K., Fuentes, J., Goldstein, A., Katul, G., Law, B.E., Lee, X., Mahli, Y., Meyers, T., Munger, W., Oechel, W., Paw, U.K.T., Pilegaard, K., Schmid, H.P., Valentini, R., Verma, S., Vesala, T., Wilson, K., Wofsy, S.W., 2001. FLUXNET: a new tool to study the temporal and spatial variability of ecosystem-scale carbon dioxide, water vapor and energyflux densities. Bull. Am. Meteorol. Soc. $82,2415-2434$.

Barford, C.C., Wofsy, S.C., Goulden, M.L., Munger, J.W., Hammond Pyle, E. Urbansky, S.P., Hutyra, L., Saleska, S.R., Fitzjarrald, D., Moore, K., 2001. Factors controlling long- and short-term sequestration of atmospheric $\mathrm{CO}_{2}$ in a mid-latitude forest. Science 294, 1688-1691.

Barr, A.G., Black, T.A., Hogg, E.H., Kljun, N., Morgenstern, K., Nesic, Z., 2004. Inter-annual variability in the leaf area index of a boreal aspen-hazelnut forest in relation to net ecosystem production. Agric. For. Meteorol. 126, 237-255.

Barr, A., Black, A.T., McCaughey, H., 2009. Climatic and Phenological Controls of the Carbon and Energy Balances of Three Contrasting Boreal Forest Ecosystems in Western Canada. Phenology of Ecosystem Processes. Springer, New York, pp. 3-34, 978-1-4419-0026-5.

Berbigier, P., Bonnefond, J.M., Mellmann, P., 2001. $\mathrm{CO}_{2}$ and water vapour fluxes for 2 years above Euroflux forest site. Agric. For. Meteorol. 108 (3), 183-197.

Burba, G., Schmidt, A., Scott, R.L., Nakai, T., Kathilankal, J., Fratini, G., Hanson, C., Law, B., McDermitt, D.K., Eckles, R., Furtaw, M., Velgersdyk, M., 2012. Calculating $\mathrm{CO}_{2}$ and $\mathrm{H}_{2} \mathrm{O}$ eddy covariance fluxes from an enclosed gas analyzer using an instantaneous mixing ratio. Global Change Biol. 18, 385-399.

Burba, G., 2013. Eddy Covariance Method for Scientific, Industrial, Agricultural and Regulatory Applications A Field Book on Measuring Gas Exchange and Aerial Emission Rates. LI-COR Biosciences, pp. 154-155.

Carrara, A., Kowalski, A.S., Neirynck, J., Janssens, I.A., Yuste, J.C., Ceulemans, R., 2003. Net ecosystem $\mathrm{CO}_{2}$ exchange of mixed forest in Belgium over 5 years. Agric. For. Meteorol. 119, 209-227, http://dx.doi.org/10.1016/S01681923(03)00120-5.

Ceulemans, R., Kowalski, A.S., Berbigier, P., Dolman, H., Grelle, A., Janssens, I.A. Lindroth, A., Moors, E., Rannik, U., (2003). Coniferous forest (Scots and Maritime Pine): carbon and water fluxes, balances, ecophysiological determinates. In: Valentini, R. (Ed.), Fluxes of Carbon, Water and Energy of European Forests. Ecological Studies, vol. 163, 2003, pp 71-97.

Chen, J., Falk, M., Euskirchen, E., Kyaw Tha Paw, U., Suchanek, T.H., Ustin, S.L., Bond, B.I., Brosofske, K.D., Phillips, N., Bi, R., 2002. Biophysical controls of carbon flows in three successional Douglas-fir stands based on eddy-covariance measurements. Tree Physiol. 22 (2-3), 169-177.

Chen, B., Black, T.A., Coops, N.C., Krishnan, P., Jassal, R., Brümmer, C., Nesic, Z., 2009 Seasonal controls on interannual variability in carbon dioxide exchange of a near-end-of rotation Douglas-fir stand in the Pacific Northwest, 1997-2006. Global Change Biol. 15 (8), 1962-1981, http://dx.doi.org/10.1111/j.1365-2486. 2008.01832.x.

Chiesi, M., Maselli, F., Bindi, M., Fibbi, L., Cherubini, P., Arlotta, E., Tirone, G. Matteucci, G., Seufert, G., 2005. Modelling carbon budget of Mediterranean forests using ground and remote sensing measurements. Agric. For. Meteorol. $135(1-4), 22-34$

Danielewska, A., Urbaniak, M., Olejnik, J., 2015. Growing season length as a key factor of cumulative net ecosystem exchange over the pine forest ecosystems in Europe. Int. Agrophys. 29 (2), 129-135, http://dx.doi.org/10.1515/intag2015-0026, 03/2015.

Dunn, A., Barforsw, C.C., Wofsy, S., Goulden, M.L., Daube, B.C., 2007. A long-term record of carbon exchange in a boreal black spruce forest: means, responses to interannual variability, and decadal trends. Global Change Biol. 12, 1-14. 
Elbers, J.A., Jacobs, C.M.J., Kruijt, B., Jans, W.W.P., Moors, E.J., 2011. Assessing the uncertainty of estimated annual totals of net ecosystem productivity: a practical approach applied to a mid latitude temperate pine forest. Agric. For. Meteorol. 151 (12), 1823-1830.

Falge, E., Baldocchi, D.D., Olson, R., Anthoni, P., Aubinet, Marc, Bernhofer, Ch., Burba, G., Ceulemans, R., ... Verma, S., ... Vesala, T., ... Wilson, K., ... Wofsy, S., 2001. Gap filling strategies for defensible annual sums of net ecosystem exchange. Agric. For. Meteorol. 107 (1), 43-69.

Falge, E., Baldocchi, D.D., Tenhunen, J., Aubinet, M., Bakwin, P., et al., 2002. Seasonality of ecosystem respiration and gross primary production as derived from FLUXNET measurements. Agric. For. Meteorol. 113, 53-74.

Foken, T., Wichura, B., 1996. Tools for quality assessment of surface-based flux measurements. Agric. For. Meteorol. 78, 83-105.

Foken, T., Gockede, M., Mauder, M., Mahrt, L., Amiro, B.D., Munger, J.W., et al., 2004. Post-field quality control. In: Lee, X. (Ed.), Handbook of Micrometeorology: A Guide for Surface Flux Measurements. Kluwer Academic, Dordrecht, pp. 81-108.

Food and Agriculture Organization of the United Nations (FAO), 2010. Global Forest Resources Assessment. Food and Agriculture Organization of the United Nations (FAO), pp. 1-378.

Forest Research Institute, 2006. Forest and forestry in European Union countries. The State Forests Information Centre, Warsaw 2006, ISBN 83-89744-41-4, 83-87647-53-5, 464 pp.

Forest Research Institute, 2013. Report on the state of forests in Poland 2012 (Raport o stanie lasów w Polsce 2012), Warszawa (2013), ISSN 1641-3229, $1-85$.

Gaumont-Guay, D., Black, T.A., Barr, A.G., Griffis, T.J., Jassal, R.S., Krishnan, P., Grant, N., Nesic, Z., 2014. Eight years of forest-floor CO2 exchange in a boreal black spruce forest: spatial integration and long-term temporal trends. Agric. For. Meteorol. 184, 25-35.

Gielen, B., De Vos, B., Campioli, M., Neirynck, J., Papale, D., Verstraeten, A., Ceulemans, R., Janssens, I.A., 2013. Biometric and eddy covariance-based assessment of decadal carbon sequestration of a temperate Scots pine forest. Agric. For. Meteorol. 174, 135-143.

Gu, L., Falge, E.M., Boden, T., Baldocchi, D.D., Black, T.A., Saleska, S.R., Suni, T., Verma, S.B., Vesala, T., Wofsy, S.C., Xu, L., 2005. Objective threshold determination for nighttime eddy flux filtering. Agric. For. Meteorol. 128, 179-197.

Hollinger, D.Y., Kelliher, F.M., Byers, J.N., Hunt, J.E., McSeveny, T.M., Weir, P.L., 1994. Carbon dioxide exchange between an undisturbed old-growth temperate forest and the atmosphere. Ecology 75 (1), 134-150.

Humphreys, E.R., Black, T.A., Morgenstern, K., Cai, T., Drewitt, G.B., Nesic, Z., Trofymow, J.A., 2006. Carbon dioxide fluxes in coastal Douglas-fir stands at different stages of development after clearcut harvesting. Agric. For. Meteorol. $140(1-4), 6-22$.

Jassal, R.S., Black, T.A., Cai, T., Eithier, G., Bruemmer, C., Nesic, Z., 2010. Impact of nitrogen fertilization on carbon and water balances in a chronosequence of three Douglas-fir stands in the Pacific Northwest. Agric. For. Meteorol. 150, $208-218$.

Köster, E., Köster, K., Aurela, M., Laurila, T., Berninger, F., Lohila, A., Pumpanen, J., 2013. Impact of reindeer herding on vegetation biomass and soil carbon content: a case study from Sodankylö, Finland. Boreal Environ. Res. 18, 35-42.

Kidston, J., Brümmer, C., Black, T.A., Morgenstern, K., Nesic, Z., McCaughey, J.H., Barr, A.G., 2010. Energy balance closure using eddy covariance above two different land surfaces and implications for $\mathrm{CO} 2$ flux measurements. Bound.-Layer Meteorol. 136 (2), 193-218, http://dx.doi.org/10.1007/s10546010-9507-y.

Kljun, N., Calanca, P., Rotach, M.W., Schmid, H.P., 2004. A simple parameterisation for flux footprint predictions. Bound.-Layer Meteorol. 112, 503-523.

Koźmiński C., Michalska B., Czarnecka M., 2007. Atlas of Climate province of West-Pomerania (Klimat województwa zachodnio-pomorskiego), Akademia Rolnicza w Szczecinie, Uniwersytet Szczeciński, 147.

Kolari, P., Pumpanen, J., Rannik, U., Ilvesniemi, H., Hari, P., Berninger, F., 2004. Carbon balance of different aged Scots pine forests in Southern Finland. Global Change Biol. 10, 1106-1119.

Krishnan, P., Black, T.A., Barr, A.G., Gaumont-Guay, D., Grant, N., Nesic, Z., 2008. Factors controlling the interannual variability in the carbon balance of a southern boreal black spruce forest. J. Geophys. Res. 113, D09109, http://dx. doi.org/10.1029/2007JD008965.

Krishnan, P., Black, T.A., Jassal, R.S., Chen, B., Nesic, Z., 2009. Interannual variability of the carbon balance of three different-aged Douglas-fir stands in the Pacific Northwest. J. Geophys. Res. 114 (G4), G04011, http://dx.doi.org/10.1029/ 2008JG000912.
Law, B.E., Williams, M., Anthoni, P.M., Baldocchi, D.D., Unsworth, M.H., 2000. Measuring and modeling seasonal variation of carbon dioxide and water vapor exchange of a Pinus ponderosa forest subject to soil water deficit. Global Change Biol. 6, 613-630.

Law, B.E., Falge, E., Gu, L., Baldocchi, D.D., Bakwin, P., Berbigier, P., et al., 2002. Environmental controls over carbon dioxide and water vapour exchange of terrestrial vegetation. Agric. For. Meteorol. 113, 97-120.

Lloyd, J., Taylor, J.A., 1994. On the temperature dependence of soil respiration. Funct. Ecol. 8 (3), 315-323.

Luyssaert, S., Inglima, I., Jung, M., Richardson, A.D., Reichstein, M., Papale, D., Piao, S.L., Schulze, E.-D., Wingate, L., Matteucci, G., Arago, L., Aubinet, M., Beer, C., Bernhofer, C., Black, K.G., Bonal, D., Bonnefond, J.-M., Chambers, J., Ciais, P., Cook, B., Davis, K.J., Dolamn, A.J., ... Valentini, R., ... Vesala, T., ... Janssens, I.A., 2007. $\mathrm{CO}_{2}$ balance of boreal, temperate, and tropical forests derived from a global database. Global Change Biol. 13, 2509-2537, http://dx.doi.org/10.1111/ j.1365-2486.2007.01439.

Massman, W.J., Lee, X., 2002. Eddy covariance flux corrections and uncertainties in long term studies of carbon and energy exchanges. Agric. For. Meteorol. 113, $121-144$

Moncrieff, J.B., Massheder, J.M., de Bruin, H., Ebers, J., Friborg, T., Heusinkveld, B., Kabat, P., Scott, S., Soegaard, H., Verhoef, A., 1997. A system to measure surface fluxes of momentum, sensible heat, water vapor and carbon dioxide. J. Hydrol. 188-189, 589-611.

Moncrieff, J.B., Clement, R., Finnigan, J., Meyers, T., 2004. Averaging, detrending and filtering of eddy covariance time series. In: Lee, X., Massman, W.J., Law, B.E. (Eds.), Dordrecht Handbook of Micrometeorology: a Guide for Surface Flux Measurements. Kluwer Academic, pp. 7-31.

Morgenstern, K., Black, T.A., Humphreys, E.R., Griffis, T.J., Drewitt, G.B., Cai, T., Nesic, Z., Spittlehouse, L.D., Livingston, N.J., 2004. Sensitivity and uncertainty of the carbon balance of a Pacific Northwest Douglas-fir forest during an El Niño/La Niña cycle. Agric. For. Meteorol. 123 (3-4), 201-219, http://dx.doi.org/ 10.1016/j.agrformet.2003.12.003.

Nagy, M.T., Janssens, I.A., Curiel Yuste, J., Carrara, A., Ceulemans, R., 2006. Footprint-adjusted net ecosystem $\mathrm{CO}_{2}$ exchange and carbon balance components of a temperate forest. Agric. For. Meteorol. 139 (3-4), 344-360.

Pan, Y., Birdsey, R.A., Fang, J., Houghton, R., Kauppi, P.E., Kurz, W.A., Phillips, O.L. Shvidenko, A., Lewis, S.L., Canadell, J.G., Ciais, P., Jackson, R.B., Pacala, S.W., McGuire, A.D., Piao, S., Rautiainen, A., Sitch, S., Haye,s, D., 2011. A large and persistent carbon sink in the world's forests. Science 333, 988-993.

Paul-Limoges, E., Black, T.A., Chrsten, A., Nesic, Z., Jassal, R.S., 2015. Effect of clearcut harvesting on the carbon balance of a Douglas-fir forest. Agric. For. Meteorol. 203, 30-42.

Pilegaard, K., Hummelshoj, P., Jensen, N.O., Chen, Z., 2001. Two years of continuous $\mathrm{CO}_{2}$ eddy-flux measurements over a Danish beech forest. Agric. For. Meteorol. 107, 29-41.

Suni, T., Rinne, J., Reissell, A., Altimir, N., Keronen, P., Rannik Ü, Dal Maso, M., Kulmala, M., Vesala, T., 2003. Long-term measurements of surface fluxes above a Scots pine forest in Hyytiälä, southern Finland, 1996-2001. Boreal Environ. Res. 4, 287-301.

Webb, E.K., Pearman, G.I., Leuning, R., 1980. Correction of flux measurements for density effects due to heat and water vapour transfer. Quart. J. R. Meteorol. Soc. 106, 85-100.

Wesely, M.L., Hart, R.L., 1985. Variability of short term eddy-correlation estimates of mass exchange. In: Hutchinson, B.A., Hicks, B.B. (Eds.), The Forest-Atmosphere Interaction. D. Reidel, Dordrecht, pp. 591-612.

World Reference Base for Soil Resources, 2006. A Framework for International Classification, Correlation and Communication. Food And Agriculture Organization Of The United Nations, Rome, pp. 2006.

Zanchi, G., Thiel, D., Green, T., Lindner, M., 2007. Forest Area Change and Afforestation in Europe: Critical Analysis of Available Data and the Relevance for International Environmental Policies Report No. 24. European Forest Institute, Joensuu, Finland.

Zha, T., Barr, A.G., Black, T.A., McCaughey, J.H., Bhatti, J., Hawthorne, I., Krishnan, P., Kidston, J., Saigusa, N., Shashkov, A., Nesic, Z., 2009. Carbon sequestration in boreal jack pine stands following harvesting. Global Change Biol. 15, 1475-1487, http://dx.doi.org/10.1111/j.1365-2486.2008.01817.x.

Zielis, S., Etzold, S., Zweifel, R., Eugster, W., Haeni, M., Buchmann, N., 2014. NEP of a Swiss subalpine forest is significantly driven not only by current but also by previous year's weather. Biogeosciences 11, 1627-1635, http://dx.doi.org/10. 5194/bg-11-1627-2014. 